Article

\title{
Fingerprints of Kamafugite-Like Magmas in Mesozoic Lamproites of the Aldan Shield: Evidence from Olivine and Olivine-Hosted Inclusions
}

\author{
Ivan F. Chayka ${ }^{1,2, *}$, Alexander V. Sobolev ${ }^{3,4}$, Andrey E. Izokh ${ }^{1,5}$, Valentina G. Batanova ${ }^{3}$, \\ Stepan P. Krasheninnikov ${ }^{4}{ }^{(}$, Maria V. Chervyakovskaya ${ }^{6}$, Alkiviadis Kontonikas-Charos ${ }^{7}$, \\ Anton V. Kutyrev ${ }^{8}{ }^{\circ}$, Boris M. Lobastov ${ }^{9}$ and Vasiliy S. Chervyakovskiy ${ }^{6}$ \\ 1 V. S. Sobolev Institute of Geology and Mineralogy Siberian Branch of the Russian Academy of Sciences, \\ 630090 Novosibirsk, Russia; izokh@igm.nsc.ru \\ 2 Institute of Experimental Mineralogy, Russian Academy of Sciences, 142432 Chernogolovka, Russia \\ 3 Institut des Sciences de la Terre (ISTerre), Université de Grenoble Alpes, 38041 Grenoble, France; \\ alexander.sobolev@univ-grenoble-alpes.fr (A.V.S.); valentina.batanova@univ-grenoble-alpes.fr (V.G.B.) \\ 4 Vernadsky Institute of Geochemistry and Analytical Chemistry, Russian Academy of Sciences, Moscow, \\ Russia; spkrash09@gmail.com \\ 5 Department of Geology and Geophysics, Novosibirsk State University, 630090 Novosibirsk, Russia \\ 6 Institute of Geology and Geochemistry, Ural Branch of the Russian Academy of Sciences, 620016 \\ Yekaterinburg, Russia; zaitseva.mv1991@gmail.com (M.V.C.); v.chervyakovskiy@mail.ru (V.S.C.) \\ 7 School of Chemical Engineering and Advanced Materials, The University of Adelaide, Adelaide, SA 5005, \\ Australia; alkiviadis.kontonikas-charos@adelaide.edu.au \\ 8 Institute of Volcanology and Seismology, Far Eastern Branch of the Russian Academy of Sciences, \\ 683000 Petropavlovsk-Kamchatsky, Russia; anton.v.kutyrev@gmail.com \\ 9 Institute of Mining, Geology and Geotechnology, Siberian Federal University, 660041 Krasnoyarsk, Russia; \\ lbm02@ya.ru \\ * Correspondence: chaikaif@igm.nsc.ru; Tel.: +7-985-799-4936
}

Received: 17 February 2020; Accepted: 6 April 2020; Published: 9 April 2020

Abstract: Mesozoic (125-135 Ma) cratonic low-Ti lamproites from the northern part of the Aldan Shield do not conform to typical classification schemes of ultrapotassic anorogenic rocks. Here we investigate their origins by analyzing olivine and olivine-hosted inclusions from the Ryabinoviy pipe, a well preserved lamproite intrusion within the Aldan Shield. Four types of olivine are identified: (1) zoned phenocrysts, (2) high-Mg, high-Ni homogeneous macrocrysts, (3) high-Ca and low-Ni olivine and (4) mantle xenocrysts. Olivine compositions are comparable to those from the Mediterranean Belt lamproites (Olivine-1 and -2), kamafugites (Olivine-3) and leucitites. Homogenized melt inclusions (MIs) within olivine-1 phenocrysts have lamproitic compositions and are similar to the host rocks, whereas kamafugite-like compositions are obtained for melt inclusions within olivine-3. Estimates of redox conditions indicate that "lamproitic" olivine crystallized from anomalously oxidized magma ( $\triangle \mathrm{NNO}+3$ to $+4 \log$ units.). Crystallization of "kamafugitic" olivine occurred under even more oxidized conditions, supported by low V/Sc ratios. We consider high-Ca olivine (3) to be a fingerprint of kamafugite-like magmatism, which also occurred during the Mesozoic and slightly preceded lamproitic magmatism. Our preliminary genetic model suggests that low-temperature, extension-triggered melting of mica- and carbonate-rich veined subcontitental lithospheric mantle (SCLM) generated the kamafugite-like melts. This process exhausted carbonate and affected the silicate assemblage of the veins. Subsequent and more extensive melting of the modified SCLM produced volumetrically larger lamproitic magmas. This newly recognized kamafugitic "fingerprint" further highlights similarities between the Aldan Shield potassic province and the Mediterranean Belt, and provides evidence of an overlap between "orogenic" and "anorogenic" varieties of low-Ti potassic magmatism. Moreover, our study also demonstrates that recycled subduction components are not an essential factor in the petrogenesis of low-Ti lamproites, kamafugites and leucitites. 
Keywords: lamproite; kamafugite; olivine; melt inclusions; Aldan shield; Siberian platform; SCLM

\section{Introduction}

Lamproites, part of the ultrapotassic subgroup of alkaline igneous rocks, are characterized by high $\mathrm{K}_{2} \mathrm{O}\left(>3\right.$ wt.\%) and $\mathrm{MgO}$, extremely high $\mathrm{K}_{2} \mathrm{O} / \mathrm{Na}_{2} \mathrm{O}$ ratios $(>3)$, and typically low $\mathrm{SiO}_{2}, \mathrm{Al}_{2} \mathrm{O}_{3}$ and $\mathrm{CaO}$. These chemical features reflect their unusual mineral assemblages, which often comprise titanian, Al-poor phlogopite, clinopyroxene, sanidine, leucite, olivine and potassic amphiboles, and lack orthopyroxene, plagioclase, nepheline and melilite [1,2]. Similar to other ultrapotassic rocks, lamproites occur within cratons and have elevated Ti contents [1-3]. However, there exists a subgroup of lamproites that are defined by anomalously low Ti and high field strength element (HFSE) concentrations. The largest and best-studied region of such low-Ti lamproite magmatism occurs within the Cenozoic Alpine-Himalayan belt (mainly in the Mediterranean) [3,4]. The Mediterranean belt is also renowned for occurrences of kamafugites and kamafugite-like rocks, which rarely associate with lamproites anywhere else in the world [5,6]. These Mediterranean-type ultrapotassic rocks are thought to have originated during post-collisional extension and melting of depleted mantle, modified by crustal contamination $[3,4,7]$.

Numerous occurrences of low-Ti lamproites have also been found within the Central Aldan high-potassic province, part of the Siberian Craton, Russia. This province formed during the Mesozoic at the Northern-Central part of the Aldan Shield, which during that time was distant from active fold belts (Pacific and Mongol-Okhot). Despite some reconstructions suggesting a crucial role for stagnant slab subduction during the Mesozoic along the Asia-Pacific convergence zone [8], the geodynamic setting of the province is typically considered to be within-plate, thus complicating the origin of the low-Ti lamproites. Most studied lamproite occurrences within the province are part of the Murun and Bilibino complexes, Yukhta, Yakokut and Ryabinoviy massifs [9-16]. Lamproite outcrops in this region are scarce and, in most cases, show evidence of substantial weathering of primary mafic minerals. However, the Ryabinoviy pipe is well exposed and preserved, thus providing an excellent opportunity for a mineralogical study.

Olivine is the first mineral crystallizing from a mafic melt and is thus a powerful petrological tool [17-20]. As such, olivine-hosted melt inclusions are good proxies for parental melts [21-24]. Although olivine-based methods have been widely applied to a number of lamproite occurrences $[18,20$, $22,25]$, there is a lack of such studies on the Aldan lamproites. Previous works on these rocks $[14,15,26]$ provide insufficient data on olivine-hosted inclusions and exclude precise olivine chemistry. Here we present a detailed study of olivine compositions and their multiphase silicate inclusions from the Ryabinoviy pipe lamproites, with implications for petrogenesis and physicochemical conditions of formation. In addition, we compare and contrast our data with occurrences of low-Ti ultrapotassic magmatism elsewhere (e.g., the Mediterranean belt).

\section{Geological Background}

The Ryabinoviy pipe belongs to the Central Aldan Mesozoic potassic province. This province is located mainly within the Nimnyr terrain of the Central Aldan super-terrain of the Aldan-Stanovoy shield $[12,27,28]$ (Figure 1). The latter forms part of the Baikal-Aldan-Stanovoy megablock, which is characterized by a gravity minimum as a result of lithosphere decompression [29]. The Central Aldan area hosts a smaller NS-striking gravity gradient zone within thin low-density crust (up to $36-38 \mathrm{~km}$ ). This zone, occurring between the Amga and Tyrkanda mélange zones, separates the Uchur and West Aldan blocks [29]. It overlaps with the Proterozoic Nimnyrskaya metallogenic (apatite-carbonatite) zone [30] and, in its Northern part, partially overlaps with the Central Aldan Mesozoic potassic province (Figure 1B). 


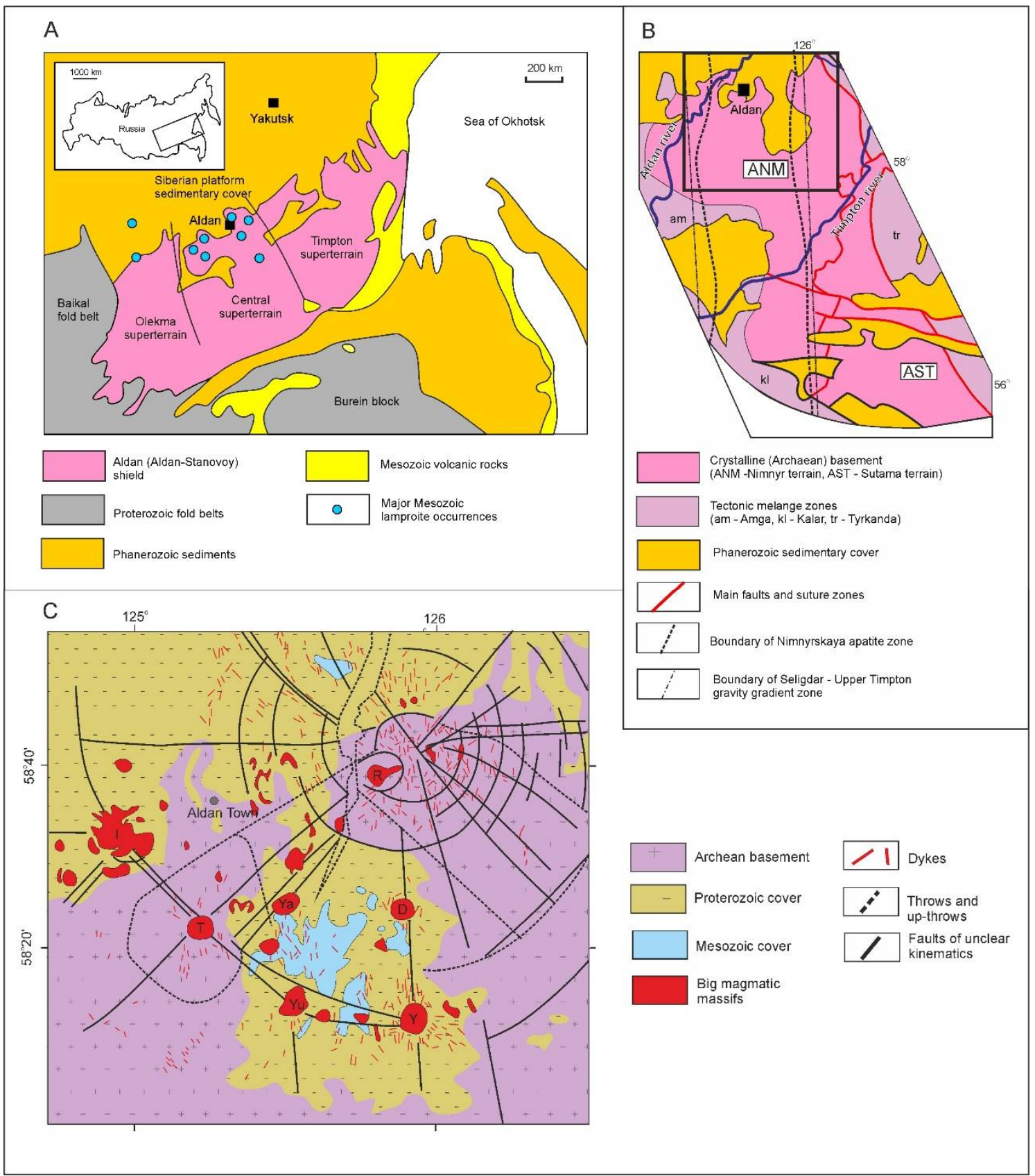

Figure 1. (A) Simplified geological map of the Aldan-Stanovoy shield and adjacent fold belts (after [12]); (B) Geological scheme of the Central Aldan super terrane (after [27,28]). A rectangle on (B) outlines the area, represented on the inset (C). (C) Simplified geological map of the Mesozoic Central Aldan potassic province (after [31]). Main intrusive massifs: I-Inagli, T-Tommot, Ya-Yakokut, Yu-Yukhtinsly; D—Dzhenkondinsky, Y-Yllymakhskiy; R-Ryabinoviy.

According to geochronological studies and terrain analysis, the formation of the Aldan-Stanovoy shield began at $3.5 \mathrm{Ga}$ and culminated at ca. $3.0 \mathrm{Ga}$. Significant tectonic events took place at 2.7 and 2.0 Ga [32]. Some authors attribute the 2.0-1.9 Ga event to the collision of Archean proto-cratons and Paleoproterozoic micro-continents, which finalized the formation of the Aldan-Stanovoy shield [33,34].

Potassic magmatism occurred during the late Mesozoic $\left(\mathrm{J}_{2}-\mathrm{K}_{1}\right)$ in the Northern part of the Aldan shield. Within the Central Aldan super terrane, this event formed the radially-concentric Central Aldan potassic province [31,35] (Figure 1C). Although it formed during several subsequent pulses, the general tectonic structure of the province and geochemical features of the rocks are uniform. [8,31]. The massifs 
consist of a complex variety of potassic rocks: leucitites, trachytes, alkali syenites, shonkinites, lamproites, lamprophyres, pyroxenites and dunites [9-11,35]. The largest massifs are located at main fault intersections, whereas smaller intrusions and dike swarms occur throughout the area (Figure 2).
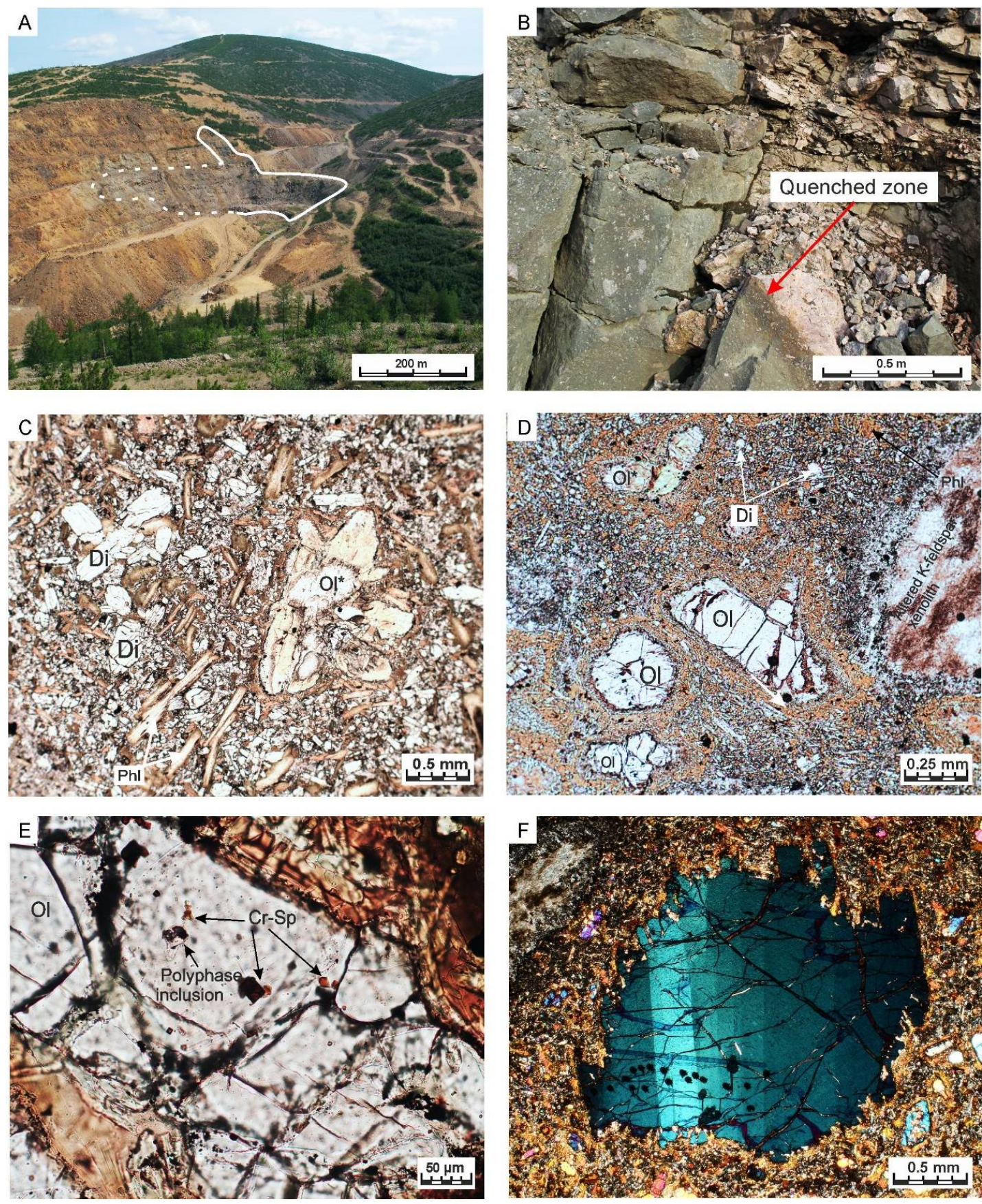

Figure 2. Relationships of the Ryabinoviy pipe with the host rocks and transmitted-light photomicrographs of the studied lamproites. (A) The pipe (outlined) within host coarse-grained syenites. (B) Quenched zone in the contact between the pipe and host syenites. (C) Lamproite from the inner part of the pipe with olivine, replaced by carbonate, serpentine and phlogopite. (D) Olivine phenocrysts in diopsidephlogopite-K-feldspar groundmass (olivine lamproite from the quenched zone of the pipe). (E) Olivine phenocryst with chromian spinel and polyphase silicate inclusions. (F) Kink-band structures in the olivine-4 grain (polarizers crossed). Abbreviations of the mineral names: Di—diopside, Phl—phlogopite, $\mathrm{Ol} —$ olivine, $\mathrm{Ol}^{*}$ — replaced olivine, $\mathrm{Cr}-\mathrm{Sp}$ —chromian spinel (chromite and magnesian chromite). 
Lamproites and lamproite-like rocks are widespread in the province and adjacent areas (Figure 1A) [12,26,35]. Lamproite magmatism occurred in two pulses, in the Late Jurassic and Early Cretaceous [11]. Despite this temporal diversity, the majority of Aldan lamproites are considered to be products of a similar magmatic process, with minor chemical differences between occurrences (e.g., variations of $\mathrm{MgO}, \mathrm{CaO}$ and $\mathrm{Al}_{2} \mathrm{O}_{3}$ contents) [12,16,26,34,36].

The Ryabinoviy massif, located in the central part of Central Aldan province, represents a polyphase magmatic structure comprised of a variety of lithologies ranging from alkaline pyroxenites and shonkinites to trachytes and alkaline syenites. Alkaline metasomatic rocks containing economic gold mineralization also broadly occur within the massif. Lamproites of the Ryabinoviy massif are locally emplaced into coarse-grained syenites and form several dikes as well as a diatreme-like body (Figure 2A). The latter has a complicated shape with several apophyses, complicating its geometrical type. The diatreme is composed of breccia with lamproitic groundmass and possesses numerous characteristics of eruptive volcanic and sub-volcanic structures (e.g., eruptive pipes). In this study we refer to this body as the "Ryabinoviy pipe". The pipe is surrounded and crosscut by a swarm of minette and microsyenite dykes, which are suggested to be co-magmatic with the lamproites [37]. A discontinuous and thin zone of rapidly-quenched lamproitic magma is observed along the contact of the pipe and host syenites (Figure 2B).

\section{Samples and Methods}

Seven samples representative of unaltered or slightly altered lamproite from the quenched zone (Figure 2B) of the Ryabinoviy pipe were collected. Whole rock compositions were obtained using XRF-analysis (ARL-9900) at the V.S. Sobolev institute of Geology and Mineralogy SB RAS (IGM SB RAS) (Novosibirsk, Russia) Olivine was analyzed both in polished thin sections and in epoxy or indium mounts with mineral separates. To obtain an extensive chemical dataset, we employed both high-precision electron microprobe methods $[17,38]$ and laser ablation inductive-coupled plasma mass spectrometry (ICP-MS). High-precision electron probe microanalysis (EPMA) was performed on a JEOL JXA-8230 at IGM SB RAS) and ISTerre (Grenoble, France) at accelerating voltage $20 \mathrm{kV}$, probe current $900 \mathrm{nA}$ and beam diameter $2 \mu \mathrm{m}$. The MongOl sh11-2 reference olivine [39] was used as the primary standard for $\mathrm{Fe}, \mathrm{Mg}$ and $\mathrm{Si}$ and analyzed as an unknown sample every 30-40 analysis to check accuracy and precision for all analyzed elements [38]. Element mapping of the olivine grains was performed on JEOL JXA-8230 at ISTerre and IGM SB RAS at current $900 \mathrm{nA}$, voltage $20 \mathrm{kV}$, beam diameter $1 \mu \mathrm{m}$ and dwell time $100 \mathrm{~ms}$. Composition of Cr-spinel crystals, enclosed within the studied olivine grains, was determined at IGM SB RAS and ISTerre, using a routine scheme on electron microprobe JEOL JXA-8230 with beam diameter of $1 \mu \mathrm{m}$ and current $20 \mathrm{nA}$.

Laser ablation ICP-MS spot analyses were performed at the Institute of Geology and Geochemistry UB RAS (Yekaterinburg, Russia) using the NexION 300 S (Perkin Elmer) quadrupole inductively coupled plasma mass spectrometer (ICP-MS) equipped with an NWR 213 (ESI) laser ablation system. The laser ablation was performed with a spot size of $25 \mu \mathrm{m}$, a pulse repetition rate of $10 \mathrm{~Hz}$ and an energy density of 10-11 J/ $\mathrm{cm}^{2}$. The results were then processed and reduced using the GLITTER V4.4 program. A NIST SRM 610 glass was used as an external standard, while NIST SRM 612 was measured as an unknown after every ten spots. The $\mathrm{SiO}_{2}$ content obtained by EPMA was used as an internal standard. The measurement error of the standard NIST 610 glass varied from $3 \%$ to $15 \%(1 \sigma)$ for the measured 161 elements, while for NIST 612 the error was from $3 \%$ to $20 \%(1 \sigma)$.

For the study of the inclusions, we prepared olivine separates from the crushed samples, applying gravitational concentration in water, magnetic separation and handpicking of grains. To homogenize melt inclusions, the olivine separates were heated in a Nabertherm RHTV 120-300/17 vertical tube furnace (Vernadsky Institute in Moscow, Russia) [40] for $10 \mathrm{~min}$ at temperatures of $1350{ }^{\circ} \mathrm{C}$ and $1250{ }^{\circ} \mathrm{C}$, which correspond to temperature ranges predicted by previous studies [15] and to our calculations (see Discussion). We performed the experiment at 1 bar $\mathrm{Ar}-\mathrm{CO}_{2}-\mathrm{H}_{2}$ atmosphere at oxygen fugacity corresponding to quartz-magnetite-fayalite (QFM) buffer in loosely closed Pt ampoules. 
To replace all atmospheric air by the controlled gas and thus prevent oxidation of Fe in olivine and $\mathrm{Cr}$-spinel, $5 \mathrm{~min}$ pre-heating to $800{ }^{\circ} \mathrm{C}$ was applied. The technique of electrical burning of the wire, which held the ampoules, enabled extremely rapid quenching of the separates and thus sufficient homogeneity of the glasses. After the experiment, we mounted the olivine grains into epoxy mounts, which were then abraded in order to bring inclusions to the surface. Grains, containing exposed melt inclusions, were picked from epoxy mounts and re-mounted into an indium mount. Major element concentrations of homogenized melt inclusions were determined at the V.S. Sobolev Institute of Geology and Mineralogy via electron microprobe analysis using both JEOL JXA-8230 and JEOL JXA-8100 instruments. The measurements were performed at voltage $20 \mathrm{kV}$ beam current $20 \mathrm{nA}$ and beam diameter $1 \mu \mathrm{m}$ with acquisition time $\sim 1 \mathrm{~min}$ for each element. Because the applied current was quite high compared to that recommended for an alkaline glass analyses [41] and could cause substantial migration and loss of $\mathrm{Na}$ and other mobile elements, the acquisition time and beam diameter were carefully calibrated on alkali-bearing standards. During this calibration and analysis of the inclusions, real-time monitoring of signal intensities was applied to obtain stable signal for the analyzed elements during the acquisition. For all microprobe analyses, samples were coated with a 25-nm carbon film.

We determined trace elements $\mathrm{F}$ and $\mathrm{H}_{2} \mathrm{O}$ concentrations in homogenized melt inclusions as well as trace element concentrations in crystalline phases of non-heated inclusions by secondary ion mass spectrometry (SIMS) at the Institute of Microelectronics (Yaroslavl', Russia) using a CAMECA IMS4-F spectrometer. The samples were coated with 30-nm-gold film and bombarded by $\mathrm{O}^{2-}$ ions. Before data acquisition, the area of analysis was sputtered for $3 \mathrm{~min}$ by $70 \mu \mathrm{m}$ beam to remove surface contamination. Volatile element analysis of the glasses was performed prior to lithophile trace element analysis in order to prevent the loss of volatiles. Volatile concentrations were determined using a $5 \mu \mathrm{m}$ beam diameter and three cycles of measurements with dynamical correction of counting time (5-120 s depending on current counting statistics). Trace element concentrations were obtained with a beam diameter of $25 \mu \mathrm{m}$ and five cycles of measurements with the same dynamical correction of counting time. Secondary ion intensities were normalized to ${ }^{30} \mathrm{Si}^{+}$and converted to weight concentrations using calibration curves based on a set of well-characterized natural and artificial glasses [23,42-45]. Corrections of isobaric interferences were applied for $\mathrm{Eu}, \mathrm{Gd}$ and $\mathrm{Er}$ [46]. We used glasses KL-2 G and ML 3 B as monitors for trace element analysis in glasses and NIST 610 for the analysis of crystalline phases (mica and clinopyroxene) of the inclusions.

The main problem of data interpretation was overheating of the inclusions that causes excess molten olivine. However, the effect of overheating on the composition of quenched inclusions appears to be negligible as part of initially molten olivine recrystallizes on the walls during quenching, and thus, any changes in element concentration are considered to be inconsequential [23]. Another problem concerns loss of volatiles from the inclusions which is thought to occur due to diffusion during rock cooling or at the heating experiment. This effect commonly causes water loss, but may also decrease concentrations of other volatile elements [47-50]. The issue becomes especially important minding that the studied inclusions are fully crystallized (see Results and Discussion for the details) and probably experienced slow cooling. For this reason we avoid considering data on $\mathrm{H}_{2} \mathrm{O}$ contents within the inclusions and exclude those from the dataset. Although in the study we present $\mathrm{Cl}, \mathrm{F}$ and $\mathrm{S}$ contents in the inclusions, one should be aware of their possible loss.

\section{Results}

\subsection{Lamproite Petrography and Geochemistry}

Lamproites from the Ryabinoviy pipe have a porphyritic texture with various amounts of phenocrysts $(0.05-1 \mathrm{~mm}$ sized euhedral grains), macrocrysts $(0.2-3 \mathrm{~mm}$ sized anhedral grains), host rock xenoliths and groundmass minerals. Within the inner part of the pipe, zoned diopside, phlogopite and olivine (partially replaced by phlogopite, serpentine and carbonate) occur as pheno- and macrocrysts, whereas sanidine, subordinate apatite and calcite comprise the groundmass (Figure 2C). 
In the quenched zone of the pipe, only olivine occurs as pheno- and macrocrysts, while microcrysts of diopside and apatite, poikilitic phlogopite and sanidine make up the groundmass (Figure 2D). Minor and opaque minerals are leucite, replaced by analcite, chromian spinel and magnetite.

Whole-rock compositions are listed in the Table S1 and Table 1. Recalculated on a 100\% volatile-free basis, the lamproites have basic to intermediate compositions of ultrapotassic to high-K affinities $\left(\mathrm{K}_{2} \mathrm{O} / \mathrm{Na}_{2} \mathrm{O}=2.7-7.5\right.$ with minor analyses having higher Na content) (Figure 3A,B). Concentration of $\mathrm{MgO}$ ranges from 11-15 wt.\%, falling into the field of the other Aldan Shield lamproites (Figure 3C) $[11,12,16]$. The $\mathrm{CaO}$ content varies between 7.2-9.2 wt.\%, whereas $\mathrm{Na}_{2} \mathrm{O}$ content is relatively low, varying from below detection limit of X-ray fluorescence analysis (XRF) to $3 \mathrm{wt} . \%$ (Figure 3B-D). According to the chemical classification of [3], the examined rocks correspond to lamproites (Figure 3C,D). Trace element systematics show enrichment of incompatible elements in the lamproites. Their contents, normalized to primitive mantle (PM) concentrations [51], decrease from $\mathrm{Rb}$ to Lu with negative $\mathrm{Ta}, \mathrm{Nb}$, Ti and $\mathrm{U}$ anomalies and positive $\mathrm{Ba}, \mathrm{K}$ and $\mathrm{Sr}$ anomalies (Figure $4 \mathrm{~A}$ ). Chondrite-normalized [52] rare earth element (REE) plots show a smooth LREE -enriched pattern with La and Lu up to 100 and seven-eight times the chondritic values, respectively (Figure 4B).

Table 1. Whole-rock composition of the Ryabinoviy pipe lamproites.

\begin{tabular}{cccccc}
\hline No. & $\mathbf{1}$ & $\mathbf{2}$ & $\mathbf{3}$ & $\mathbf{4}$ & $\mathbf{5}$ \\
\hline Sample ID & $\mathbf{5 1 - 1 2}$ & $\mathbf{I 5 2 - 1 2}$ & $\mathbf{I 5 8 - 1 2}$ & $\mathbf{I 5 5 - 5 - 1 2}$ & $\mathbf{5 0 - 1 2}$ \\
\hline $\mathrm{SiO}_{2}$ & 47.35 & 47.50 & 49.07 & 48.77 & 52.12 \\
$\mathrm{TiO}_{2}$ & 0.74 & 0.71 & 0.74 & 0.73 & 0.72 \\
$\mathrm{Al}_{2} \mathrm{O}_{3}$ & 9.35 & 8.51 & 10.48 & 9.51 & 12.71 \\
$\mathrm{Fe}_{2} \mathrm{O}_{3}$ (total) & 9.61 & 9.57 & 9.06 & 9.19 & 8.55 \\
$\mathrm{MnO}$ & 0.15 & 0.15 & 0.15 & 0.14 & 0.13 \\
$\mathrm{MgO}$ & 13.01 & 14.90 & 10.90 & 12.46 & 6.79 \\
$\mathrm{CaO}$ & 8.82 & 8.43 & 8.46 & 8.33 & 6.93 \\
$\mathrm{Na}{ }_{2} \mathrm{O}$ & 1.33 & 1.26 & 2.10 & 0.83 & 3.62 \\
$\mathrm{~K}_{2} \mathrm{O}$ & 5.75 & 5.79 & 5.56 & 6.42 & 5.13 \\
$\mathrm{P}_{2} \mathrm{O}_{5}$ & 0.77 & 0.80 & 0.70 & 0.72 & 0.54 \\
$\mathrm{BaO}$ & 0.28 & 0.29 & 0.37 & 0.31 & 0.21 \\
$\mathrm{SO}$ & 0.18 & 0.21 & 0.32 & 0.42 & 0.21 \\
$\mathrm{~V}_{2} \mathrm{O}_{5}$ & 0.03 & 0.03 & 0.03 & 0.03 & 0.03 \\
$\mathrm{Cr}_{2} \mathrm{O}_{3}$ & 0.15 & 0.16 & 0.11 & 0.13 & 0.04 \\
$\mathrm{NiO}_{\mathrm{LOI}}^{2}$ & 0.03 & 0.04 & b.d.1 & b.d.l. & 0.01 \\
$\mathrm{Total}^{2}(\mathrm{With}$ & 1.80 & 1.44 & 1.91 & 1.52 & 1.57 \\
$\mathrm{LOI}$ & 99.34 & 99.79 & 99.95 & 99.50 & 99.30 \\
\hline
\end{tabular}

${ }^{1}$ b.d.l.-below detection limit; ${ }^{2}$ LOI-loss on ignition.

\subsection{Olivine Morphology and Chemistry}

In the lamproites, olivine forms transparent, fractured grains of various sizes $(0.05-5 \mathrm{~mm})$ and morphologies (Figure 2C-F). Many grains are extensively replaced by phlogopite, serpentine and carbonate (Figure 2C,D). The complete chemical dataset of olivine is given in Table S2, while the most distinctive features are provided below (Table 2). We distinguished four types of olivine, based on their occurrence and chemistry. 

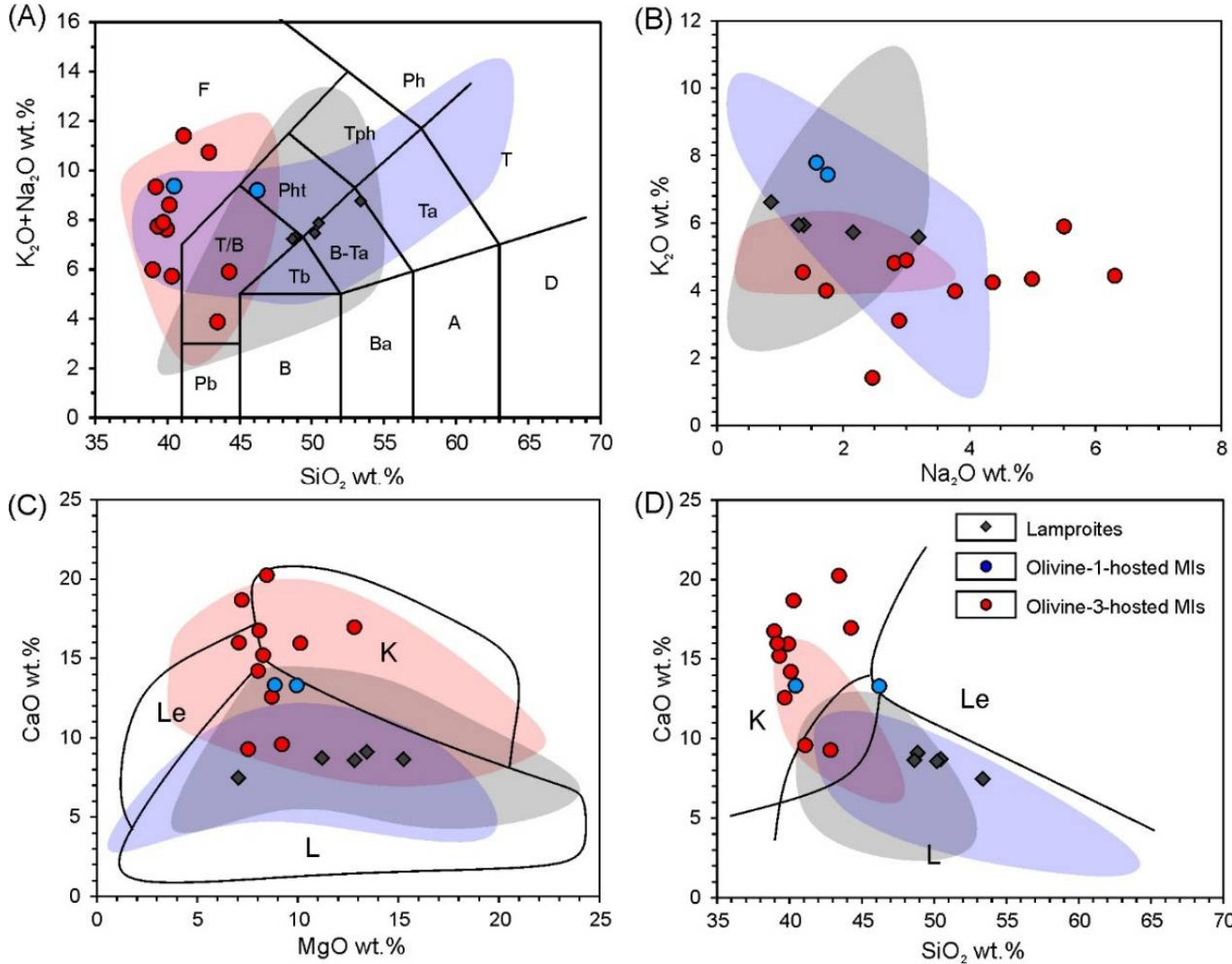

Figure 3. Major element variation diagrams for the studied rocks and homogenized melt inclusions. Fields for comparison: grey-Aldan Shield lamproites, blue-Mediterranean lamproites, red-Mediterranean kamafugites and high-Ca leucitites. Compositions used for the fields are from GeoRoc database (http://georoc.mpch-mainz.gwdg.de/georoc/, accessed on 25 September 2019). Fields for lamproites (L), kamafugites (K) and leucitites (Le) are outlined as in [3]. Fields on total alkalis—silica (TAS) plot [53] on inset (A) are labeled with the following abbreviations: $\mathrm{F}$-foidite, $\mathrm{Ph}$-phonolite, Tph-tephriphonolite, Pht-phonotephrite, T/B-tephrite/basanite, $\mathrm{Pb}$ - picrobasalt, $\mathrm{Tb}$ - trachybasalt, $\mathrm{B}-\mathrm{Ta}$-basaltic trachyandesite, Ta-trachyandesite, $\mathrm{T}$ - trachyte/trachydacite, $\mathrm{D}$-dacite, $\mathrm{A}$-andesite, Ba-basaltic andesite, B-basalt. (B) $\mathrm{K}_{2} \mathrm{O}-\mathrm{Na}_{2} \mathrm{O}$ plot; (C) $\mathrm{CaO}-\mathrm{MgO}$ plot with outlined classification fields [3]; (D) $\mathrm{CaO}-\mathrm{SiO}_{2}$ plot with outlined classification fields [3].

(A)

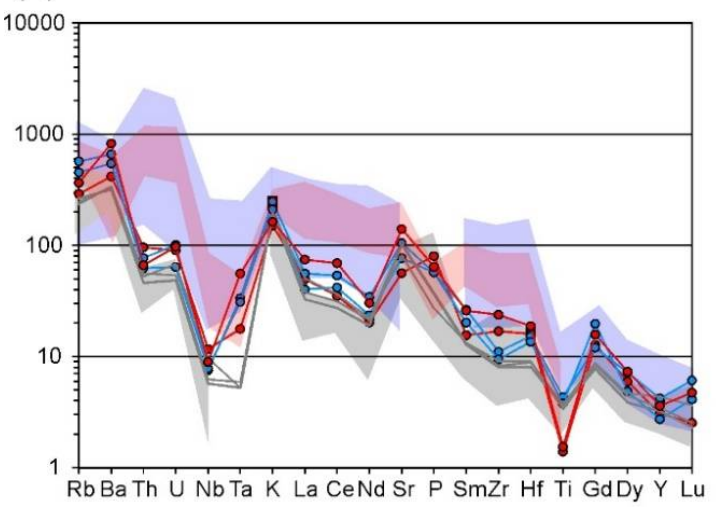

(B)



Figure 4. Trace element variations in the studied rocks and melt inclusions. (A) PM-normalized trace element diagram [51]. (B) Chondrite-normalized REEs diagram [52]. Fields for comparison are as on Figure 3. 
Table 2. Types and main characteristics of olivine from the studied rocks.

\begin{tabular}{|c|c|c|c|c|}
\hline Attribute & Olivine-1 & Olivine-2 & Olivine-3 & Olivine-4 \\
\hline Occurrence & $\begin{array}{l}\text { Crystal-shaped or } \\
\text { rounded grains, } \\
\text { forming majority of } \\
\text { olivine in the rocks }\end{array}$ & $\begin{array}{l}\text { Large resorbed } \\
\text { grains with a rim of } \\
\text { olivine-1; cores in } \\
\text { olivine-1. }\end{array}$ & $\begin{array}{l}\text { Large (up to } 1 \mathrm{~mm} \text { ) } \\
\text { transparent grains } \\
\text { in crushed samples }\end{array}$ & $\begin{array}{c}\text { Large resorbed } \\
\text { grains with a rim of } \\
\text { olivine-1; cores in } \\
\text { olivine-1. }\end{array}$ \\
\hline $\begin{array}{l}\text { Amount of analyses } \\
\text { (EPMA/LA-ICP-MS) }\end{array}$ & $259 / 18$ & $174 / 20$ & $116 / 31$ & $292 / 20$ \\
\hline $\mathrm{Mg \#}$ & $91.56(2.25)^{1}$ & $94.6(0.5)$ & $94.5(0.2)$ & $92.3(0.36)$ \\
\hline $\mathrm{NiO}$, wt. $\%$ & $0.41(0.07)$ & $0.50(0.07)$ & $0.27(0.02)$ & $0.40(0.03)$ \\
\hline $\mathrm{CaO}$, wt. $\%$ & $0.16(0.04)$ & $0.09(0.01)$ & $0.35(0.04)$ & $0.006(0.008)$ \\
\hline $\mathrm{Al}, \mathrm{ppm}$ & $65(19)$ & $101(20)$ & $57(29)$ & $3(5)$ \\
\hline $\mathrm{Na}, \mathrm{ppm}$ & $40(21)$ & $36(9)$ & $188(96)$ & $6(6)$ \\
\hline Li, ppm & $4.9(2.1)$ & $2.5(0.73)$ & $2.8(1)$ & $2.3(0.9)$ \\
\hline $\mathrm{V} / \mathrm{Sc}$ & $1.7(2.1)$ & $1.1(0.4)$ & $0.1(0.06)$ & $0.5(0.3)$ \\
\hline Zoning/inhomogeneity & $\begin{array}{l}\text { Distinct step-like } \\
\text { zoning }\end{array}$ & $\begin{array}{l}\text { Absent except for } \\
\text { highly-incompatible } \\
\text { elements }\end{array}$ & $\begin{array}{c}\text { Absent except } \\
\text { occasional linear } \\
\text { anomalies of } \mathrm{Ca} \\
\text { and Na contents }\end{array}$ & Absent \\
\hline Inclusions (Cr-spinel) & Yes & Yes & No & No \\
\hline Inclusions (Melt) & $\begin{array}{l}\text { Common, but too } \\
\text { small for analysis }\end{array}$ & No & $\begin{array}{l}\text { Rare, but sufficient } \\
\text { for examination }\end{array}$ & No \\
\hline Origin $^{2}$ & $\begin{array}{l}\text { Relatively rapid } \\
\text { crystallization in } \\
\text { shallow-level } \\
\text { chambers. }\end{array}$ & $\begin{array}{l}\text { Slow crystallization } \\
\text { from lamproitic } \\
\text { melt in a deep } \\
\text { chamber. }\end{array}$ & $\begin{array}{l}\text { Trapped as } \\
\text { xenocrysts from } \\
\text { cumulates of } \\
\text { kamafugite-like } \\
\text { magma }\end{array}$ & $\begin{array}{c}\text { Xenocrysts of } \\
\text { sub-continental } \\
\text { lithospheric mantle }\end{array}$ \\
\hline
\end{tabular}

${ }^{1}$ Mean values and standard deviation (in parentheses); ${ }^{2}$ See Discussion.

Olivine- 1 forms euhedral, fractured grains ranging from 0.05 to $1 \mathrm{~mm}$ in size and are transparent and dusty in appearance. This type of olivine contains abundant $\mathrm{Cr}$-spinel microcrysts, secondary and primary multiphase inclusions (Figure $2 \mathrm{E}$ ). It is also characterized by wide compositional ranges and zoning with decreasing $\mathrm{Mg \#}, \mathrm{NiO}$ and $\mathrm{Al}_{2} \mathrm{O}_{3}$ and increasing $\mathrm{CaO}, \mathrm{ZnO}$ and $\mathrm{Na}_{2} \mathrm{O}$ from cores to rims (Figures 5-8). The Mg\# varies from 85 to 93 mole \% with the main mode at 92.5 with some values $<85$ in altered rims (Figures 7 and $8 \mathrm{~A}$ ). Concentrations of $\mathrm{NiO}$ range from 0.15 to $0.5 \mathrm{wt} . \%$, while $\mathrm{CaO}$ generally does not exceed $0.2 \mathrm{wt} . \%$ (Figure $7 \mathrm{~A}, \mathrm{~B}$ and Figure $8 \mathrm{~A}-\mathrm{C}$ ). Both $\mathrm{NiO}$ and $\mathrm{Al}_{2} \mathrm{O}_{3}$ are positively correlated with $\mathrm{Mg \#}$, whereas $\mathrm{CaO}, \mathrm{MnO}, \mathrm{Zn}$ and Ti concentrations show the reverse trend (Figure 7).

Olivine-2 forms large grains (up to $5 \mathrm{~mm}$ ) and is strongly fractured with few $\mathrm{Cr}$-spinel inclusions and dusty swarms of $\mu \mathrm{m}$-sized secondary inclusions. In crossed polarized light, kink-band intragrain structures are occasionally observed. These grains are mostly resorbed and mantled by a rim of olivine-1 (Figure 5A). This olivine may also form smaller cores in olivine-1 (Figures 5B and 6A-D). Olivine- 2 is characterized by high Mg\# values (generally $94.5-95)$ and high $\mathrm{NiO}$ content $(0.45-0.6 \mathrm{wt} . \%)$ (Figure 5A,B, Figure 7A, Figure 8D,E). Trace element concentrations in olivine-2 are equal or lower compared with olivine-1, aside from $\mathrm{Al}$, which may reach $150 \mathrm{ppm}$, higher than in olivine-1 (40-120 ppm) (Figure 5A,B, Figure 7, Figure 8).

Found only in crushed samples, olivine- 3 occurs as transparent grains and which are generally only distinguished by chemistry. These grains occasionally host multiphase silicate inclusions, needle-like Cr-spinel lamellae (too thin for EPMA) and display healed fractures, revealed only by EPMA mapping (Figure 6K). Olivine-3 is characterized by a narrow range of extremely high Mg\# values (94-95 mole \%) and elevated $\mathrm{CaO}$ contents, ranging from $0.24-0.46 \mathrm{wt} . \%$. Concentrations of $\mathrm{NiO}$ are relatively low $(0.26-0.28 \mathrm{wt} . \%)$ and deviates from the Ni-Mg correlation trend typical for igneous olivine (Figure 7A,B 
and Figure 8G-I). Spatial elemental distribution is relatively homogeneous with minor variations in some incompatible elements (within EPMA error), with the exception of $\mathrm{CaO}$, which shows significant depletion along healed fractures (Figure 6I-L).
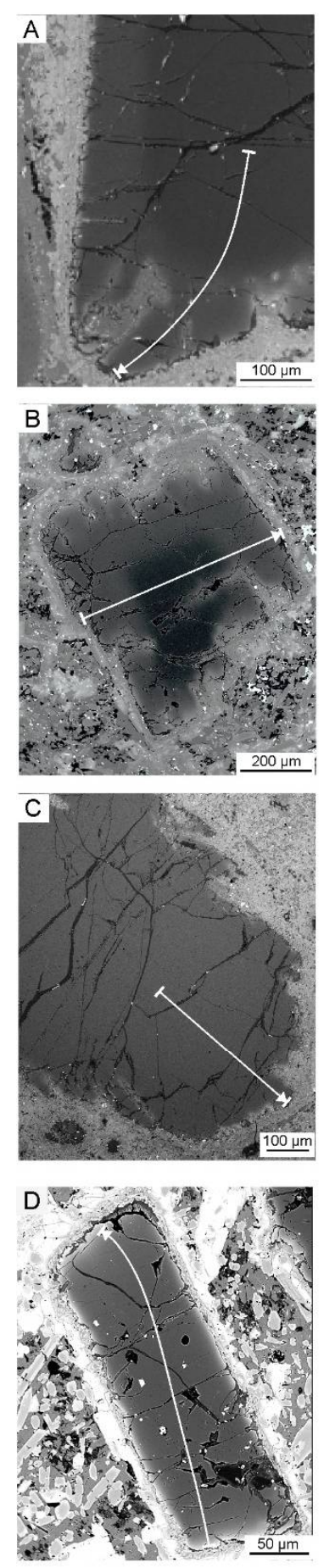
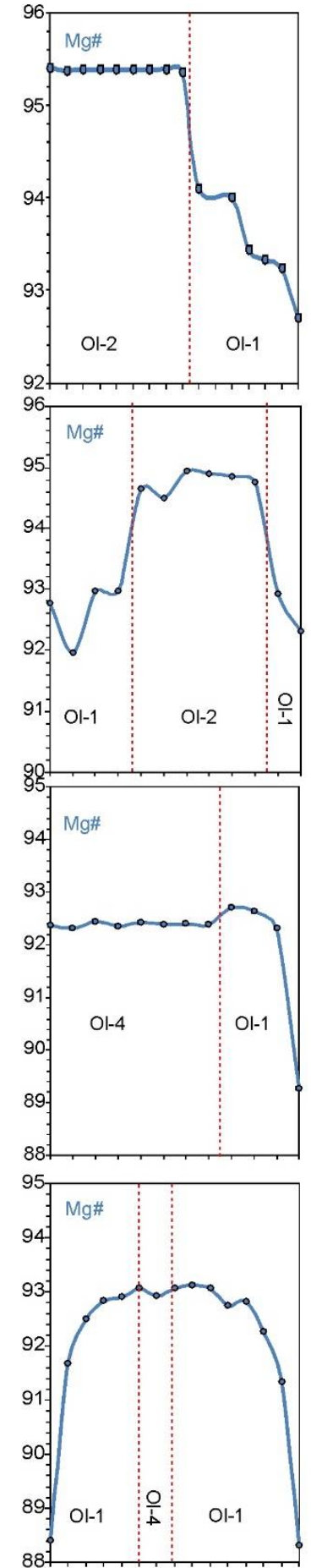
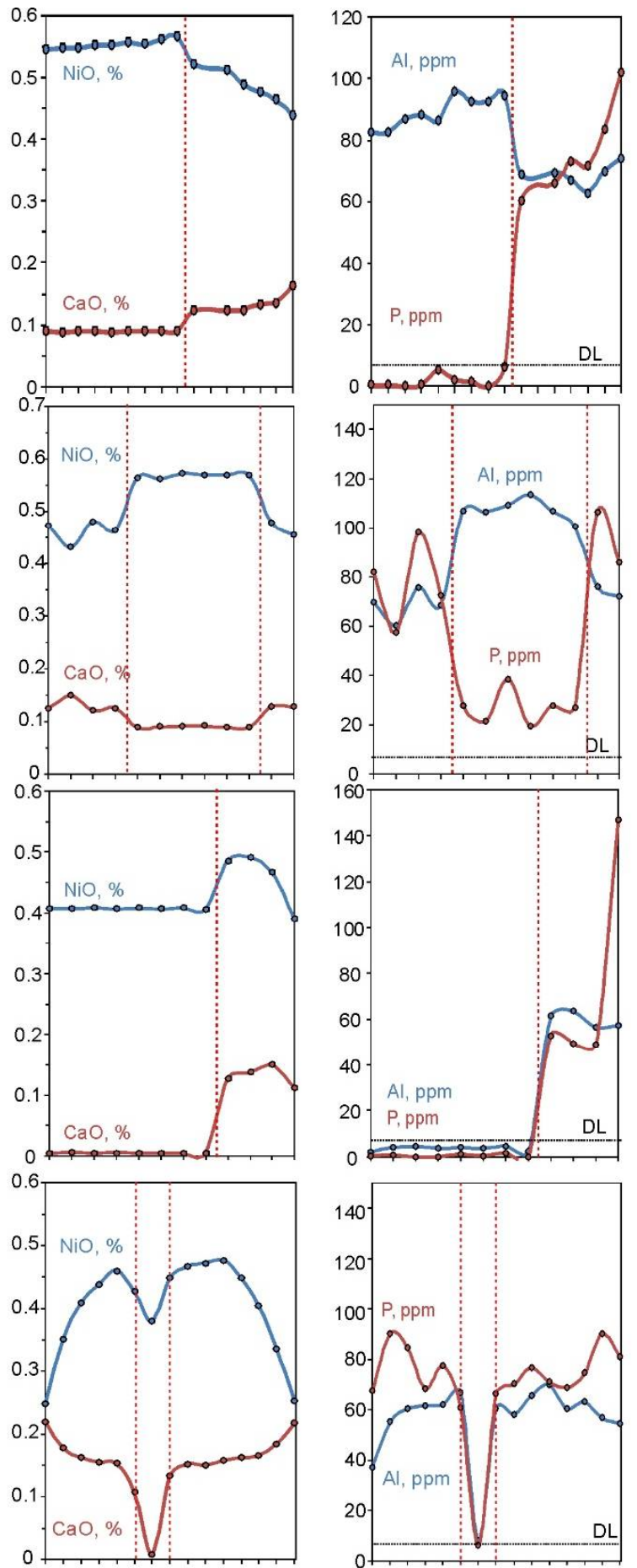

Figure 5. SEM BSE images and EPMA element profiles of olivine grains. (A) Olivine-2 with a rim of olivine-1. (B) Olivine-1 with an olivine-2 core. (C) Olivine-4 with a rim of olivine-1. (D) Olivine-1 with an olivine-4 core. White arrows on the SEM BSE images show compositional profile directions. Abbreviations: DL—detection limit, $\mathrm{Ol}$-olivine. 
Similar to olivine-2, olivine-4 forms large resorbed fractured grains, overgrown by a rim of olivine-1, or small resorbed cores within olivine-1 (Figure 5C-E and Figure 6E-H). Aside from clusters of $\mu \mathrm{m}$-scale secondary inclusions, it lacks $\mathrm{Cr}$-spinel and/or multiphase inclusions. In crossed polarized light, kink-band intragrain structures are observed within some olivine-4 grains (Figure 2F). The composition of this type of olivine differs significantly from the aforementioned types. It is characterized by $\mathrm{Mg \#}$ values of 92-93 and exceptionally low trace element concentrations, with the exception of $\mathrm{NiO}(0.2-0.46$ wt.\%) (Figures 7 and 8 ).
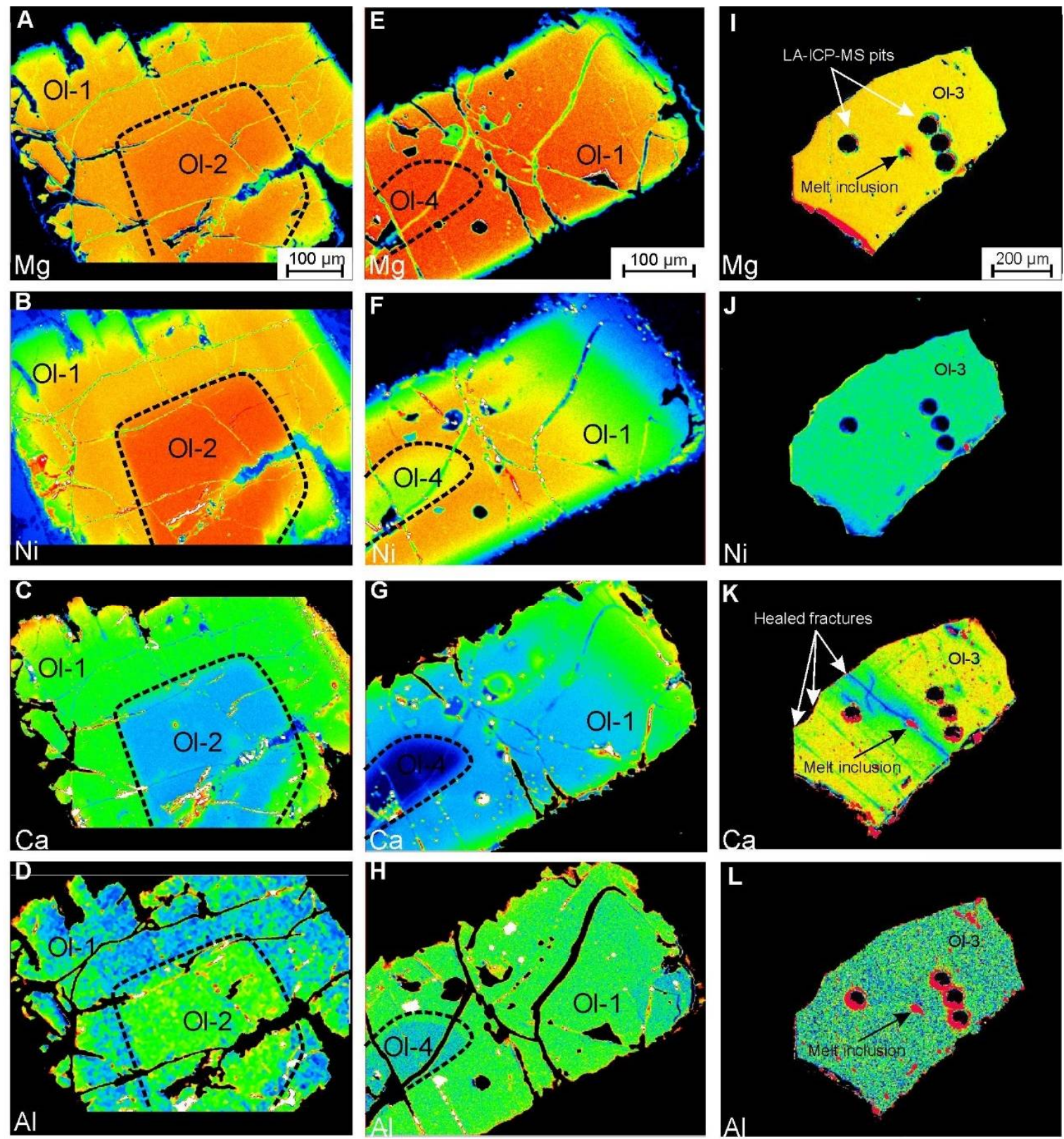

Low

Signal intensity

\section{High}

Figure 6. Representative electron microprobe (CPS) maps of the olivine grains. (A-D) olivine-1 grain with core of olivine-2 (see Figure 5B); (E-H) —olivine-1 with core of olivine-4 (see Figure 5D); (I-L) - olivine-3 grain. Elements, which distribution was mapped are specified on each inset. 

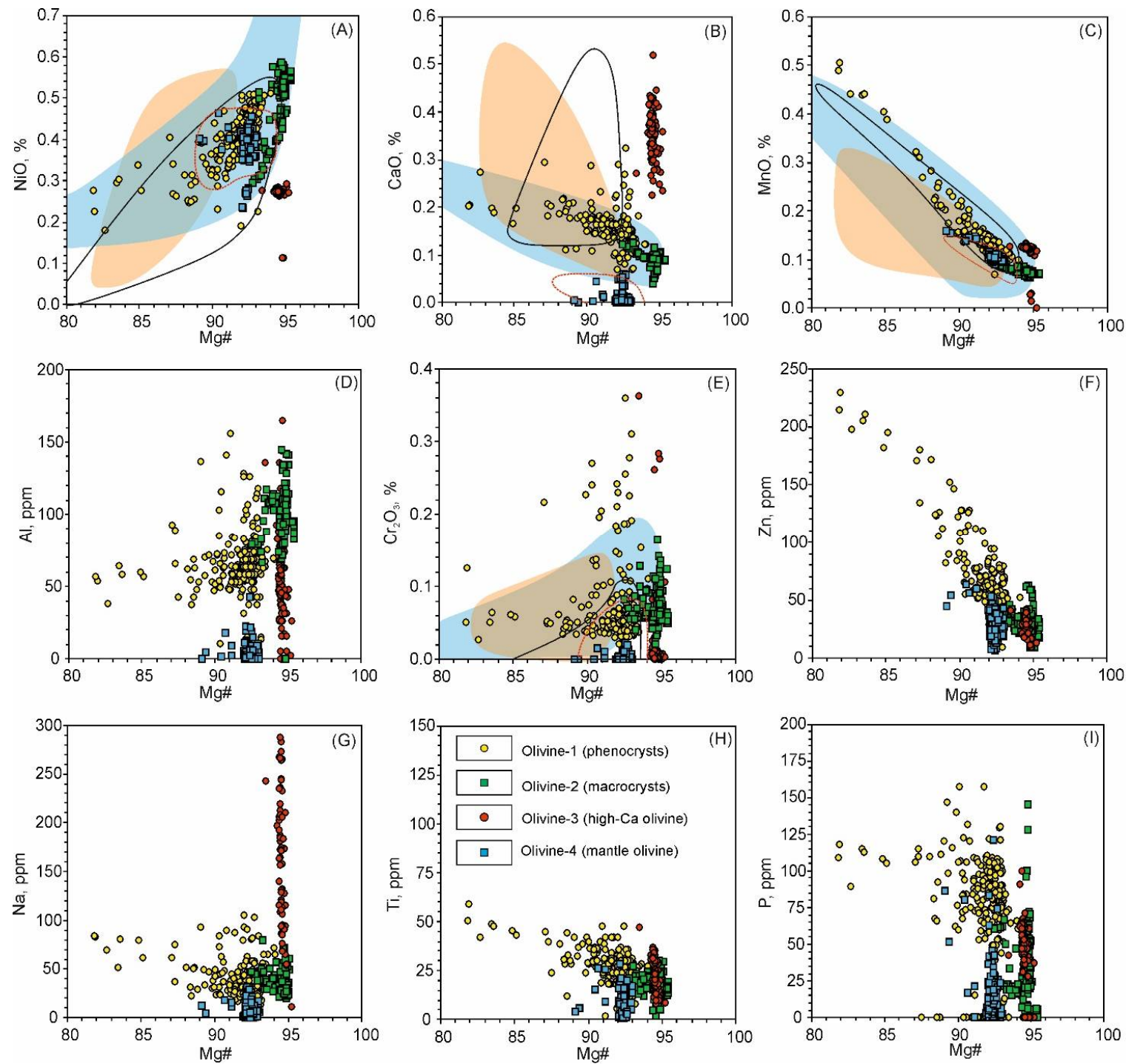

Figure 7. Binary elemental plots showing variation in olivine types. (A) $\mathrm{NiO}-\mathrm{Mg} \#$ binary plot; (B) $\mathrm{CaO}-\mathrm{Mg} \#$ binary plot; (C) $\mathrm{MnO}-\mathrm{Mg} \#$ binary plot; (D) Al-Mg\# binary plot; (E) $\mathrm{Cr}_{2} \mathrm{O}_{3}-\mathrm{Mg \#}$ binary plot; (F) Zn-Mg\# binary plot; (G) Na-Mg\# binary plot; (H) Ti-Mg\# binary plot; (I) $\mathrm{P}-\mathrm{Mg \#}$ binary plot. Oxide concentrations are plotted in weight \%, element concentrations-in parts per million (ppm). Fields for comparison: blue-low-Ti lamproites worldwide, pink-high-Ti lamproites worldwide, black outline-kamafugites, red outline-mantle olivine compositions. Fields are outlined using data from GeoRoc database (http://georoc.mpch-mainz.gwdg.de/georoc/, accessed 25 September 2019), [54] and [55]. 

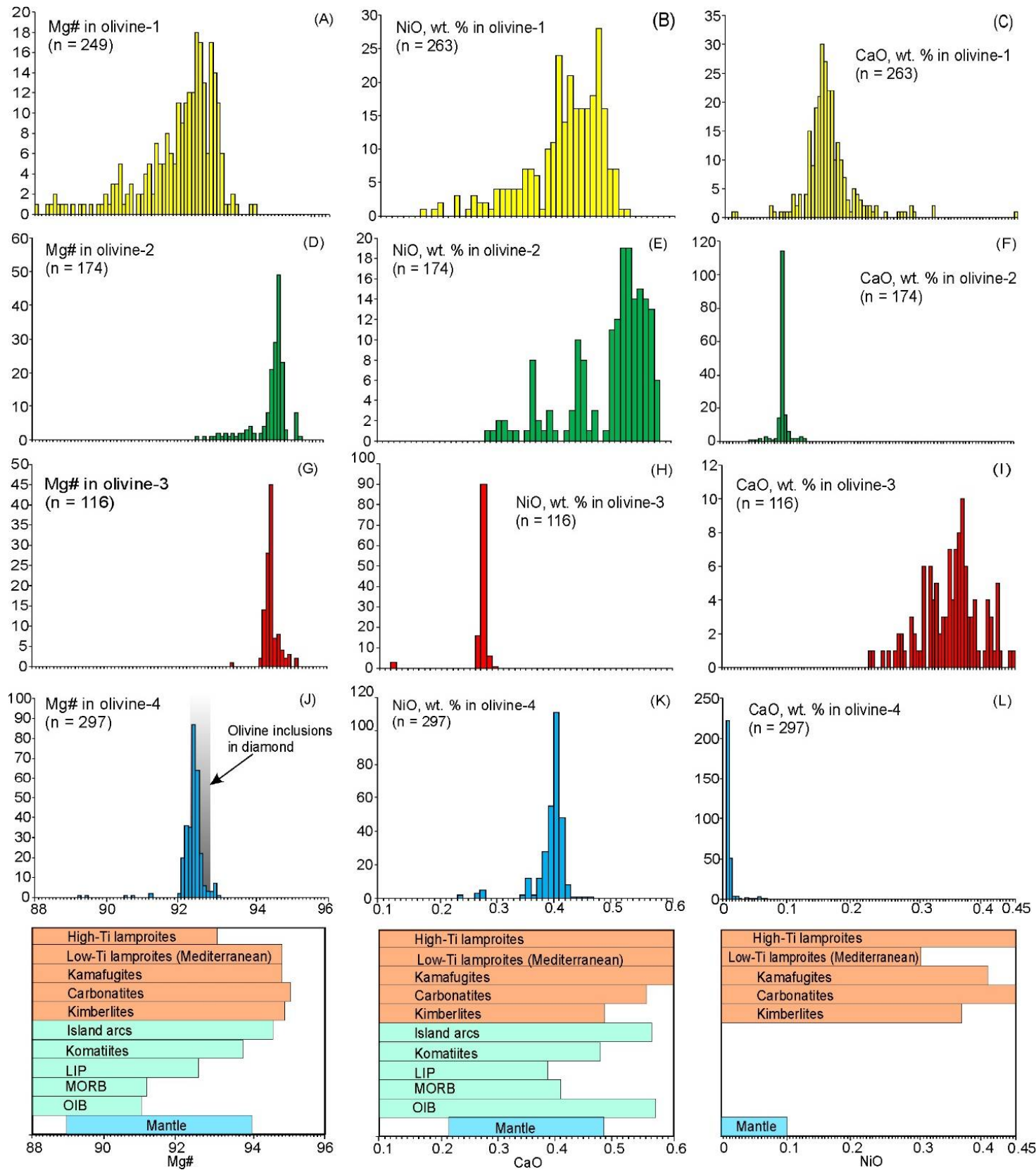

Figure 8. Probability density plots of the $\mathrm{Mg}, \mathrm{NiO}$ and $\mathrm{CaO}$ contents in olivine. Reference bars below the plots are based on data from GeoRoc database (http://georoc.mpch-mainz.gwdg.de/georoc/, accessed 25 September 2019), [56] and [57]. Specified on insets (A-L) are parameters, which are plotted on a certain chart, and total number of the analyses.

\subsection{Olivine-Hosted Silicate Inclusions}

Silicate-dominated inclusions are found in olivine- 1 and olivine- 3 . Olivine-1 hosts abundant inclusions, most of which are rather small $(<5 \mu \mathrm{m})$ and form clusters along healed fractures, thus being considered as secondary. Bona fide primary inclusions are quite rare in both types of olivine, varying in size from 5 to $20 \mu \mathrm{m}$. Inclusions hosted by olivine- 1 consist primarily of phlogopite, clinopyroxene with minor calcite, apatite and sulfides (Figure 9A). Inclusions within olivine-3 contain sodium-rich phlogopite and monticellite (Figure 9B). Partly homogenized melt inclusions both olivine-1 and olivine-3 appear as light brown glasses with a gas bubble (Figure 9C,D) and sometimes with Cr-spinel micro-grains $(<1 \mu \mathrm{m})$. The size of analyzed inclusions ranges from 5-20 $\mu \mathrm{m}$ (generally 7-12 
$\mu \mathrm{m})$. Representative chemical compositions of the heated inclusions are listed in Table 3, while whole dataset is provided in Table S3.

Table 3. Representative chemical compositions of the experimentally re-homogenized melt inclusions glasses.

\begin{tabular}{|c|c|c|c|c|c|c|c|c|c|c|c|}
\hline MI Label & O11-12 & Ol1-15 & Ol2-1 & O12-2 & O12-3 & O12-7 & Ol12-12 & O12-13 & O12-14 & O12-22 & Ol-25 \\
\hline O1 Type & 1 & 1 & 3 & 3 & 3 & 3 & 3 & 3 & 3 & 3 & 3 \\
\hline $\mathrm{SiO}_{2}$ & 46.22 & 40.44 & 44.26 & 40.3 & 43.44 & 39.93 & 42.86 & 40.11 & 39.32 & 39.69 & 41.10 \\
\hline $\mathrm{TiO}_{2}$ & 0.93 & 0.93 & 0.3 & 0.27 & 0.3 & 0.34 & 0.23 & 0.18 & 0.19 & 0.33 & 0.35 \\
\hline $\mathrm{Al}_{2} \mathrm{O}_{3}$ & 8.05 & 9.2 & 8.29 & 8.67 & 7.82 & 10.09 & 13.79 & 12.21 & 12.57 & 11.36 & 12.29 \\
\hline $\mathrm{FeO}$ (total) & 6.42 & 12.55 & 5.21 & 12.67 & 13.36 & 9.68 & 12.03 & 11.69 & 11.42 & 10.69 & 11.16 \\
\hline $\mathrm{MnO}$ & 0.09 & 0.08 & 0.08 & 0.11 & 0.1 & 0.08 & 0.17 & 0.14 & 0.15 & 0.14 & 0.14 \\
\hline $\mathrm{MgO}$ & 9.95 & 8.85 & 12.82 & 7.22 & 8.45 & 10.14 & 7.53 & 8.02 & 8.28 & 8.71 & 9.21 \\
\hline $\mathrm{CaO}$ & 13.28 & 13.33 & 16.95 & 18.67 & 20.23 & 15.95 & 9.28 & 14.2 & 15.2 & 12.57 & 9.57 \\
\hline $\mathrm{Na}_{2} \mathrm{O}$ & 1.76 & 1.58 & 1.36 & 1.73 & 2.47 & 2.81 & 6.31 & 4.37 & 3.78 & 3 & 5.5 \\
\hline $\mathrm{K}_{2} \mathrm{O}$ & 7.43 & 7.79 & 4.54 & 3.99 & 1.41 & 4.81 & 4.43 & 4.24 & 3.98 & 4.89 & 5.9 \\
\hline $\mathrm{P}_{2} \mathrm{O}_{5}$ & 1.23 & 1.4 & 1.74 & 0.99 & 0.26 & 2.67 & 1.02 & 1.18 & 1.19 & 1.39 & 1.5 \\
\hline $\mathrm{SO}_{3}$ & 0.28 & 0.29 & 0.05 & 0.17 & 0.04 & 0.05 & 0.1 & 0.09 & 0.09 & 0.25 & 0.1 \\
\hline $\mathrm{Cl}$ & 0.46 & 0.2 & 0.06 & 0.29 & 0.09 & 0.22 & 0.19 & 0.22 & 0.28 & 0.19 & 0.26 \\
\hline $\mathrm{F}$ & 0.4 & & 0.09 & & & & & & & 0.11 & \\
\hline Total & 97.5 & 97.64 & 98.75 & 98.08 & 100.97 & 99.77 & 100.94 & 99.65 & 99.45 & 96.32 & 100.08 \\
\hline $\mathrm{Li}$ & 10 & & 3 & & & & & & & 4 & \\
\hline $\mathrm{Rb}$ & 360 & & 183 & & & & & & & 231 & \\
\hline $\mathrm{Ba}$ & 4592 & & 2901 & & & & & & & 5726 & \\
\hline Th & 7 & & 8 & & & & & & & 6 & \\
\hline $\mathrm{U}$ & 2 & & 2 & & & & & & & 2 & \\
\hline $\mathrm{Ta}$ & 1 & & 1 & & & & & & & 2 & \\
\hline $\mathrm{Nb}$ & 5 & & 8 & & & & & & & 6 & \\
\hline $\mathrm{La}$ & 38 & & 34 & & & & & & & 51 & \\
\hline $\mathrm{Ce}$ & 95 & & 62 & & & & & & & 122 & \\
\hline $\mathrm{Nd}$ & 46 & & 27 & & & & & & & 41 & \\
\hline $\mathrm{Sr}$ & 2210 & & 1187 & & & & & & & 2944 & \\
\hline $\mathrm{Sm}$ & 12 & & 7 & & & & & & & 11 & \\
\hline $\mathrm{Zr}$ & 123 & & 189 & & & & & & & 266 & \\
\hline $\mathrm{Hf}$ & 5 & & 5 & & & & & & & 6 & \\
\hline $\mathrm{Gd}$ & 7 & & 8 & & & & & & & 9 & \\
\hline Dy & 5 & & 4 & & & & & & & 5 & \\
\hline Y & 19 & & 14 & & & & & & & 16 & \\
\hline Er & 2 & & 2 & & & & & & & 2 & \\
\hline $\mathrm{Yb}$ & 2.5 & & 0.5 & & & & & & & 0.6 & \\
\hline $\mathrm{Lu}$ & 0.4 & & 0.2 & & & & & & & 0.3 & \\
\hline
\end{tabular}

Only two analyses of heated inclusions hosted by olivine- 1 could be accurately determined due to their small size, ubiquitous depressurizing, and leaking during the experiment. Both have basic-to-ultrabasic peralkaline compositions with a distinct ultrapotassic affinity, $\mathrm{MgO}$ concentrations of 9-10 wt.\% and elevated $\mathrm{CaO}$ (ca. $13 \mathrm{wt} . \%$ ). Plotted on the classification diagrams [3], these data do not distinctly occur within any group of ultrapotassic rocks, rather they are "transitional" and plot between typical kamafugites and typical lamproites (Figure 3).

Analyses of glasses of the heated olivine-3 hosted inclusions were more numerous and successful than for olivine-1. Additionally, having ultrabasic to basic and peralkaline to alkaline affinities, they are characterized by a broad range of strongly elevated $\mathrm{CaO}(9-24 \mathrm{wt} . \%)$ and significant variation in alkali contents with $\mathrm{K}_{2} \mathrm{O}$ varying from 1.5 to $6 \mathrm{wt} . \%$ and $\mathrm{Na}_{2} \mathrm{O}$ from 1.5 to $6 \mathrm{wt} . \%$. These compositions fall into the kamafugites and leucitites fields based on the classification outlined by [3] (Figure 3).

Incompatible element concentrations in the glasses of the heated inclusions show moderate variance (Table 3, Table S3). Inclusions hosted by both olivine-1 and olivine-3 have almost identical trace element systematics, aside from Ti, which is higher in olivine-1, and $\mathrm{Zr}$, which is higher in olivine-3 
(Figure 4A). Plotted on a spider diagram, PM-normalized [51] values of incompatible elements show uniform enriched patterns with distinct negative anomalies for $\mathrm{Ta}, \mathrm{Nb}$ and $\mathrm{Ti}$, and positive anomalies for K, Sr, U and Gd (Figure 4A). Chondrite-normalized [52] REE plots show smooth enriched patterns for the inclusions in both types of olivine, being very similar to whole-rock compositional trends of the lamproites (Figure 4B).
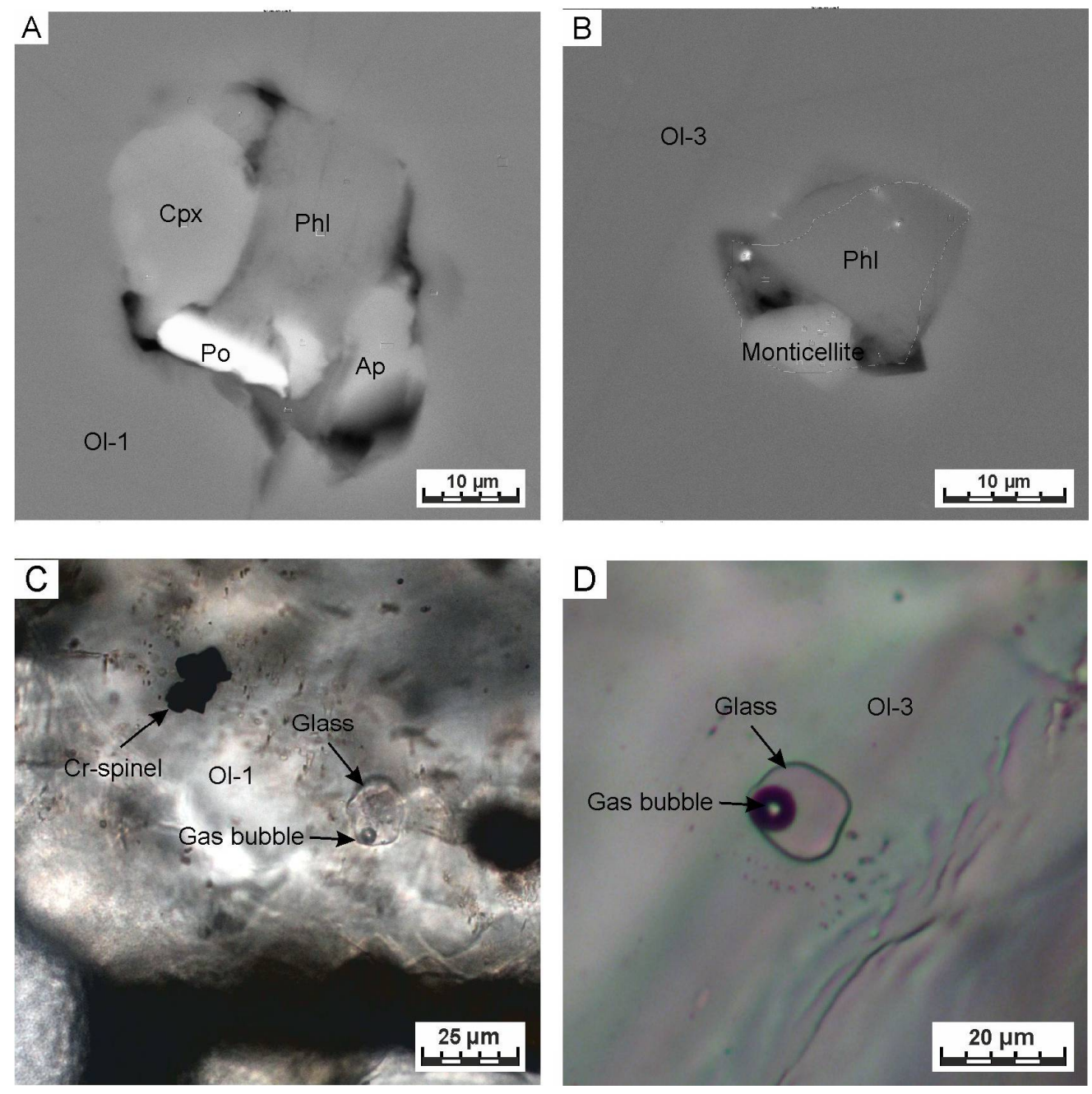

Figure 9. Representative microphotographs of the olivine-hosted inclusions. (A,B) Unheated inclusions within the olivine-1 and the olivine-3, respectively (SEM BSE photo). (C,D) Heated and quenched inclusions within the olivine-1 and the olivine-3, respectively (transmitted light). Abbreviations: Ol—olivine, Cpx—clinopyroxene, Phl—phlogopite, Ap—apatite, Po-pyrrhotite.

\subsection{Olivine-Hosted Cr-Spinel Inclusions}

Inclusions of Cr-spinel are abundant in olivine-1 and are less common in olivine-2. Having tetrahedral or octahedral morphologies, they form either single crystals within enclosing olivine or intergrowths of two to five crystals (Figure 2E). The majority of inclusions vary in size from 2 to $7 \mu \mathrm{m}$, yet individual grains are larger (up to $15 \mu \mathrm{m}$ ). Data on Cr-spinel compositions are listed in Table S4. Chemical composition of Cr-spinel enclosed within olivine-1 and olivine-2 is characterized by Mg\# ranging from 20 to 75 and corresponds to chromite and magnesio-chromite $(\mathrm{Cr} \#=83-96)$. Importantly, olivine-1 hosted Cr-spinel inclusions show a broad range of Mg\# values, whereas $\mathrm{Mg \#}$ is $>55$ for olivine-2 hosted $\mathrm{Cr}$-spinel inclusions. The analyzed $\mathrm{Cr}$-spinel inclusions have quite low $\mathrm{TiO}_{2}$ content, which does not exceed $1 \mathrm{wt}$ \%, and is lower than in $\mathrm{Cr}$-spinel from the other known lamproite occurrences (even lower than in Cr-spinel from low-Ti lamproites). 


\section{Discussion}

Based on the above petrographic observations and chemical data, interpretations can be made regarding the petrogenetic evolution of the Ryabinoviy pipe of the Central Aldan Mesozoic potassic province. In this section, we discuss the chemistry of the multiple olivine generations, and their respective $\mathrm{Cr}$-spinel and melt inclusions, with implications for petrogenesis as well as physicochemical conditions of the parental magma.

\subsection{Olivine Chemistry}

Although multiple olivine generations are quite typical in lamproite and kimberlite occurrences $[20,58,59]$, it is unusual to observe four olivine types within a single hand specimen. Varying in appearance and chemistry, each of the studied olivine types invokes potentially different origins. High-forsterite olivine is typical for a range of rocks (ultrabasic volcanic rocks, cumulates of ultrabasic magmas (dunites, pyroxenites and troctolites), mantle rocks and skarns) [60,61], and thus, some of the studied olivine may have xenocrystic origins from surrounding lithologies. However, we rule out a skarn source based on local skarn occurrences (within aureoles of the Ryabinoviy massif) being forsterite-free [62]. In addition, the underlying lithologies are dominated by felsic basement rocks of the Aldan shield which contains very little to no carbonate.

\subsubsection{Olivine-1: "Ordinary" Phenocrysts}

Olivine-1, forming the majority of the total olivine content in the studied lamproites and displaying major and trace element core-to-rim zonation, is, thus, considered to be a liquidus phase that crystallized during the early stages of magma evolution. The composition and evolutionary trends of olivine-1 are similar to those of olivine from other low-Ti lamproites (the Mediterranean belt and Northern Vietnam) and are distinct from those of high-Ti lamproites (Gaussberg, Smoky Butte, Aillik, Indian and Australian) (Figure 7A-C,E). Concentrations of $\mathrm{P}$ are elevated compared to olivine from high-Ti lamproites of West Kimberley, Australia and low-Ti lamproites from Northern Vietnam, but are quite similar to those of olivine from lamproites and other potassic rocks of the Mediterranean belt $[63,64]$. In contrast, $\mathrm{Li}$ and $\mathrm{Zn}$ contents in olivine- 1 are significantly lower than those in olivine from lamproites and other high-potassic rocks from the Mediterranean belt $[18,62]$. Although Li can reach elevated values in rims of olivine- 1 ( $>3 \mathrm{ppm}$ ), this feature is more likely due to later magma differentiation rather than representing primary melt compositions (Figure 10A).

\subsubsection{Olivine-2: "Cumulate-Derived" Macrocrysts}

Although differentiated from other generations, olivine-2 possesses several similarities with olivine-1. Plotted on binary diagrams, compositions of olivine-2 follow olivine- 1 chemical trends, but have markedly higher Mg\# than olivine-1 (Figure 7). This fact implies that olivine-2 likely crystallized from compositionally similar magma to the studied lamproites, but under different circumstances. Typical features of olivine- 2 are a lack of zonation and a narrow range of compatible elements concentrations (Figure 5A,B, Figure 6A-D, Figures 7 and 8). Similar characteristics have been reported for olivine from dunites and are interpreted to be a result of extensive diffusion and re-equilibration during slow cooling of the cumulate layer $[65,66]$. Some individual olivine-2 grains display kink-band structures, which imply they experienced ductile deformation in a solid or near-solid medium. Therefore, olivine- 2 is interpreted to have crystallized from a lamproite magma, similar to the parental of olivine-1, which subsequently dwelled as a cumulate within the magma chamber, prior to transport via a secondary magmatic pulse. 



Figure 10. Characteristic elemental variations in olivine. Fields on $(\mathbf{A}, \mathbf{B})$ are based on data from $[18,20]$. Fields for lamproitic and leucititic olivine on (C,D) are as given in [67].

\subsubsection{Olivine-3: A Fingerprint of a High-Ca Potassic Magma}

Found only within the crushed samples, olivine-3 forms segregations or small xenoliths irregularly distributed throughout the studied lamproite, making observation in thin sections difficult. Another complication is that this type of olivine, characterized by extremely-high Mg\# values, elevated Ca and relatively low $\mathrm{Ni}$, falls outside typical magmatic correlation trends. Some previous studies affiliate such high-Mg\# and high-Ca olivine in potassic rocks to calcareous skarns [68]. Regardless, due to the geological setting of the Ryabinoviy pipe, such an origin is unlikely in this case. Mantle xenocrysts, derived from extremely depleted lithospheric mantle, can possess Mg\# up to 95.5 mole \% [56], but do not contain such anomalously high concentrations of $\mathrm{CaO}$ (Figures 7 and 8). Therefore, features of olivine- 3 are best attributed to a magmatic process.

Many geochemical properties of olivine-3 are similar to those reported for olivine from the Mediterranean belt kamafugites and leucitites. High Ca and low Ni concentrations for olivine-3 are characteristic of high-Ca potassic rocks of the Roman Comagmatic Province (Italy) [22,66]. Plotted on $\mathrm{Ni} / \mathrm{Mg}-\mathrm{Mn} / \mathrm{Fe}$ and $\mathrm{Ni} / \mathrm{Mg}-\mathrm{Ca} / \mathrm{Fe}$ diagrams, olivine-3 compositions fall into the ranges of the olivine from the Roman Comagmatic Province leucitites (Figure 10C,D). In addition, P concentrations of olivine-3 (40-70 ppm) are comparable to olivine from the San Venanzo kamafugites (Italy) [63]. However, high $\mathrm{Mg} \#$ values of olivine-3 are greater than those typical for high-Ca rocks from the Mediterranean belt and other kamafugites worldwide (Figures 7 and 8G). Elevated Mg\# is believed to result from crystallization or equilibration in highly oxidized conditions. It has been shown that under high oxygen fugacity, magmatic olivine becomes almost pure forsterite due to trivalent Fe preventing substitution of $\mathrm{Mg}^{2+}$ within the olivine crystal lattice $[56,69]$. Highly oxidized conditions of olivine-3 crystallization are consistent with low V/Sc ratios (Figure 10B). As such, we suggest that olivine-3 
originated from high-Ca alkaline magma, similar to kamafugites or Roman Comagmatic Province leucitites, but in anomalously oxidized conditions.

Similarities in Co, Zn, P, Ti and Li concentrations between olivine-1, -2 and -3 (Figures 7 and $10 \mathrm{~A}, \mathrm{C})$ may be indicative of a common genetic link.

\subsubsection{Olivine-4: Mantle Xenocrysts}

Based on its high Mg\#, moderate $\mathrm{Ni}$ and strong depletion in many trace elements, olivine-4 appears to be genetically unrelated to other olivine in the studied lamproites. Rather, the presence of kink-band intragrain structures, observed in coarse olivine- 4 grains (Figure 2F), result from ductile deformation and are typical for olivine from deformed coarse-grained mantle peridotites and metamorphosed ultramafic complexes [70]. This along with an absence of inclusions (solid or melt), draws into question its magmatic origin. Olivine-4 is compositionally similar to olivine from the mantle of the central Siberian Craton and elsewhere, which have low $\mathrm{Ca}, \mathrm{Al}$ and Ti contents $[18,58,59,71-73]$.

Within the SCLM of the Siberian Platform, Mg\# in olivine is strongly controlled by pressure and depth [74]. Based on this, olivine-4 chemistry (Mg\# 92-93) corresponds to formation in the upper-middle part of the SCLM (depth $\sim 110-160 \mathrm{~km}$ and pressure $\sim 30-50 \mathrm{kbar}$ ). Fertility of the mantle is often based on Mg\# values and certain trace elements (e.g., Ti and Al) in olivine. In general, $\mathrm{Mg} \#$ values tend to increase, whereas $\mathrm{Al}$ and especially Ti decrease with progressive depletion of the mantle $[75,76]$. Olivine- 4 chemistry follows such trends and is affiliated with cratonic mantle peridotites (Figure 8J) of a depleted mantle source. Additionally, Ti concentrations within olivine- 4 are close to the lowest recorded in peridotite olivine [76] and, along with the presence of minor spinel or garnet in the source, correspond to ultra-depleted peridotites.

Numerous studies indicate that $\mathrm{Fe}, \mathrm{Mn}, \mathrm{Zn}, \mathrm{V}, \mathrm{Sc}$ and $\mathrm{Zr}$ are sensitive to the presence of spinel and garnet in mantle assemblages. According to [77], the studied olivine-4 (FeO 7-8 wt.\%) fits in the garnet peridotite range (Figure 11A). However, trace element discrimination diagrams are ambiguous: on the Sc-Zr plot, the compositions are transitional between the "spinel" and "garnet" fields, while on the Al-Mn plot, they correspond primarily to the "spinel" field (Figure 11B,C). However, data obtained by [77], show that Mn is not very sensitive to the presence of spinel or garnet. Low Y (below detection limits) and broad variations in $\mathrm{Zn}$ content in olivine- 4 is more akin to garnet peridotites, rather than from spinel [76]. In addition, the presence of Cr-pyrope xenocrysts in the lamproite and lamprophyre dikes provide further evidence of garnet prevalence in the SCLM parental magma for the Aldan lamproites [78].

Although pressure could not be estimated here, we calculated the temperatures for a range of pressures (30-50 kbar) using an equation calibrated on olivine from garnet peridotites [71,76]. The obtained temperatures are very low, varying from 650 to $980^{\circ} \mathrm{C}$, depending on pressure (Figure 11D). If spinel controlled olivine-4 composition rather than garnet in this case, a rough estimation based on temperature-dependent $\mathrm{Ca}$ and Ti regressions [77] also yields temperatures below $1000{ }^{\circ} \mathrm{C}$. Hence, regardless of the garnet or spinel prevalence in the SCLM, the estimated temperature ranges correspond to cratonic or "low continental" heat flows (30-40 $\mathrm{mW} / \mathrm{m}^{2}$ ) [79] (Figure 11D). 

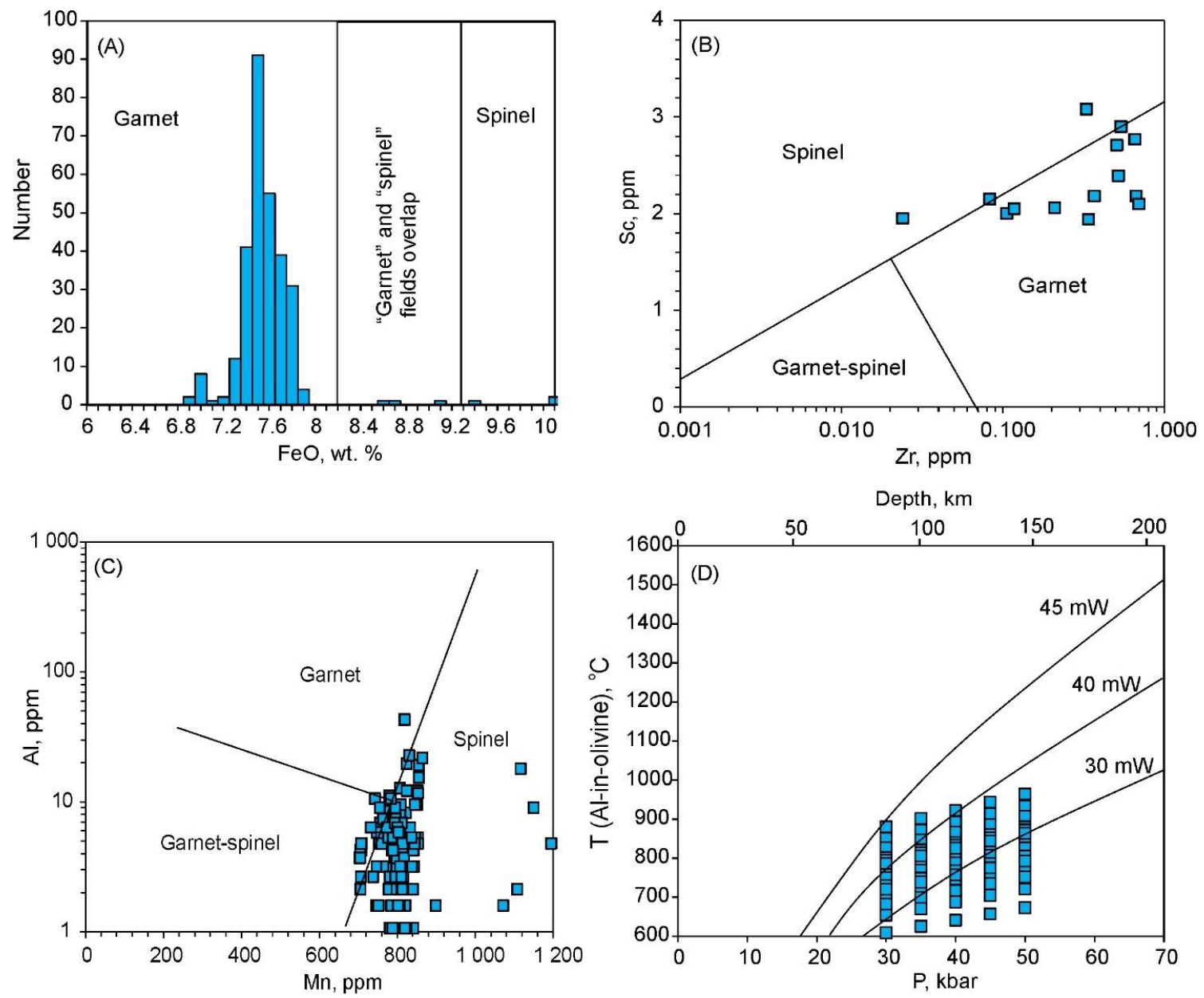

Figure 11. Element variations in olivine-4 (A-C) and PT-diagram with temperatures calculated assuming garnet is in equilibrium with olivine-4. On (A) intervals for garnet and spinel peridotites are as in [77]. On (B) and (C) fields for garnet, spinel and spinel-garnet peridotites are as in [76]. Pressures and temperatures on (D) are estimated using data in [71], and the equation from [76], respectively; heat flow curves are from [79].

\subsection{Olivine-Hosted Melt Inclusions—Evidence of Lamproite-Kamafugite Magmatism}

Primary inclusions and crystalline phases observed within both olivine- 1 and -3 require further discussion. As no glass was identified within unheated inclusions, we cannot be confident that they truly represent entrapped melt. Nevertheless, estimations based on the trace element budget (see Appendix A) support the suggestions that they represent fully crystallized melt and can be addressed as "melt inclusions" or "MIs".

Containing major diopside, phlogopite and minor apatite, olivine-1-hosted inclusions are mineralogically similar to the lamproites, particularly those containing only minor sanidine. Although we were unable to obtain ample data from these inclusions, the two compositions are generally similar to the bulk compositions of the studied lamproites. A significant difference in Ca and Si content might be tentatively attributed to silicate-carbonate immiscibility which, according to previous studies [14], occurred around $\sim 1100{ }^{\circ} \mathrm{C}$ during the evolution of the Ryabinoviy pipe lamproites. Olivine- 1 may have thus trapped melt prior to immiscibility, potentially altering the $\mathrm{Ca}$ and $\mathrm{Si}$ budget and producing the observed differences.

Unheated inclusions, hosted by olivine-3, are different from those within olivine-1. Comprising monticellite, phlogopite and Na-phlogopite, their compositions do not correspond to lamproites; rather, they are closer to kimberlites or carbonatites [2,80]. Bulk compositions of the homogenized inclusions 
also differ from lamproites and, based on the chemical classification scheme of [3], form part of the kamafugite group. However, the $\mathrm{K}_{2} \mathrm{O} / \mathrm{Na}_{2} \mathrm{O}$ ratio for many of these inclusions is lower than that required for ultrapotassic rocks. Thus, their compositions are not sensu stricto kamafugitic and should be classified as "alkaline kamafugite-like."

Very peculiar features of the inclusions hosted by olivine-3 are the broad ranges of $\mathrm{CaO}$ and $\mathrm{Na}_{2} \mathrm{O}$ contents, which do not follow typical "magmatic" trends (Figure 3B,C). However, EPMA maps may provide insight on the possible origin of such compositions (Figure $6 \mathrm{~K}$ ). In the mapped grain, two generations of olivine are observed: one is primary and the other, with lower $\mathrm{CaO}$ content and comprising healed fractures, is secondary (Figure 6K). As the melt inclusion is located along the healed fracture, we suggest that it is secondary or pseudo-primary and was entrapped during fracture healing. Since this is revealed only by the EPMA map but is not evident from optical observation and even EPMA spot analysis, we cannot exclude that some other inclusions within olivine- 3 are associated with healed fractures as well. As those fractures are healed and recrystallized into Ca-poor olivine, we suggest that inclusions located along such fractures also contain less Ca than the parental melt. Therefore, we assume that bona fide primary MIs, hosted by olivine-3, are characterized by the highest obtained $\mathrm{CaO}$ values, thus distinctly corresponding to kamafugite-like magmas (Figure 3C,D).

In a simplified genetic model, we propose that olivine-1 and -2 crystallized from lamproitic melt (LAM), whereas high-Ca olivine from a kamafugite-like melt (KAM). An important question is whether these melts are genetically linked. Crucially, trace element systematics among olivine generations reveal many similarities between olivine- $1,-2$ and -3 , whereas contents of the incompatible lithophile elements in LAM and KAM are almost equal (Figure 4). This implies that these melts originated from the same or at least a similar mantle source. In addition, [11] reported presence of high-Ca olivine, similar to the one studied here, in the majority of the Aldan lamproites. This provides further support for the link between lamproitic and kamafugite-like types of magmatism.

Hence, we propose that kamafugite-like magmatism occurred within the Central Aldan area in the Mesozoic and was temporally and spatially linked with lamproitic magmatism. We can also tentatively assert that kamafugite-like magmatism was generated slightly before lamproitic, based on considerably higher $\mathrm{CaO}$ and lower $\mathrm{Al}_{2} \mathrm{O}_{3}$ in olivine from the Late Jurassic lamproites of the Central Aldan [11]. This age-dependent chemical trend may also reflect a continuous transition from high-Ca potassic (i.e., kamafugite-like) rocks to low-Ca lamproites.

\subsection{Olivine-Hosted Cr-Spinel Inclusions: Temperature and Redox-State}

Using the "Al-in-olivine" geothermometer [81], we determined crystallization temperature ranges for olivine- 1 and -2 based on olivine-chromite pairs (in equilibration) (Figure 13A). The obtained estimates range from $1150{ }^{\circ} \mathrm{C}(\mathrm{Mg} \# 88)$ to $1370{ }^{\circ} \mathrm{C}(\mathrm{Mg} \# 95)$. However, these temperatures are lower than those obtained for high-Mg olivine from typical within-plate mafic-ultramafic rocks (Figure 12A), implying a lower temperature for the parental melt, and thus, likely a low-temperature mechanism for source melting.

The redox state of the primary melt can be calculated using mineral oxybarometers [82-84], and may also be roughly estimated from the V/Sc ratio in olivine $[18,85]$. The "classic" olivine-spinel oxybarometer [82], is known to be applicable only for rocks saturated in orthopyroxene and yields maximum $\mathrm{fO}_{2}$ in alkaline rocks [84]. However, it can be applied for alkaline rocks by introducing silica activity correction $[84,86]$. In our study we roughly estimated silica activity based on Ca content in olivine, enclosing Cr-spinel inclusions [87]. In Table S5, the listed fugacities are calculated using both the original oxybarometer [82] and with silica activity correction. The range of $\log \left(f \mathrm{O}_{2}\right)$, estimated for olivine- 1 and olivine- 2 using these assumptions, lies 3-4 log units above the NNO buffer with a slight temperature-dependent decrease. This range corresponds to relatively oxidized conditions and is higher than most of the known lamproites occurrences worldwide, including from the Mediterranean belt $[6,83,84]$ (Figure 13B). Although we were unable to calculate redox parameters 
for the KAM, extremely low V/Sc ratio in olivine-3 implies its crystallization in strongly oxidized conditions, more oxidized than estimates for the LAM (Figure 10B).


Figure 12. Schematic detailing the simplified genetic model for generation of the kamafugite-like (KAM) and lamproite (LAM) melts from a veined and modified lithospheric source. (A) Initial stage before the activation; (B) First stage: generation of a kamafugite-like melt; (C) Temperature increase and re-fertilization of the veined SCLM; (D) Extensive melting and generation of a lamproite melt.
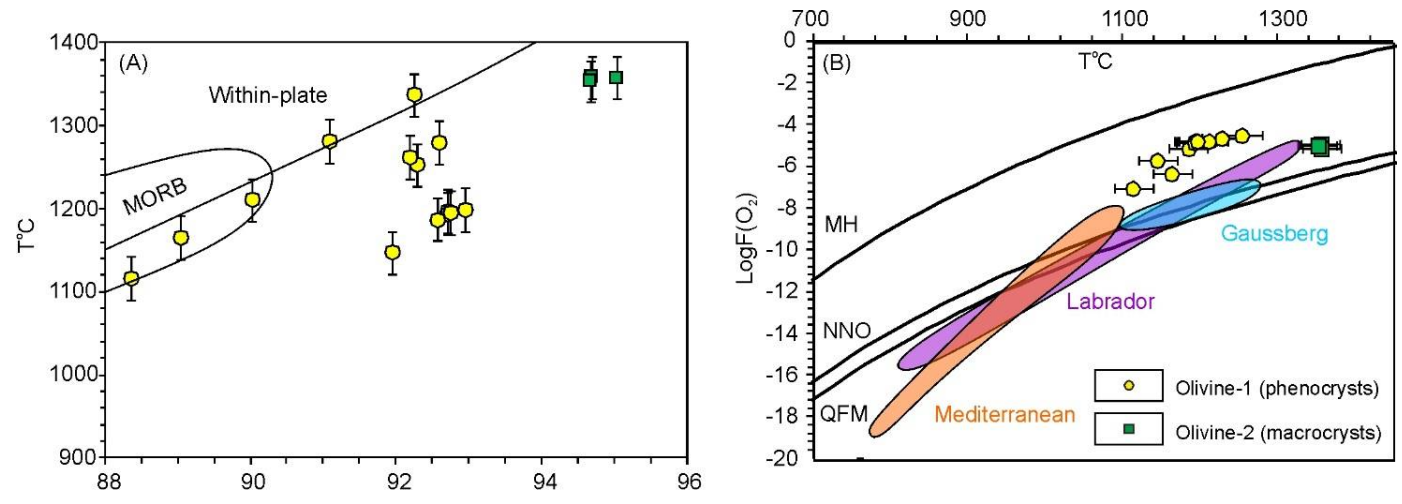

Figure 13. Results of olivine-spinel thermometry and oxybarometry, applied to olivine-1 and olivine-2. In (A), reference fields for olivine from MORB and within-plate basalts are drawn using data from [65] and [81]. In (B), reference fields for lamproites from different localities are outlined using data from [6], [83] and [84]. The numerical data is listed in Table S5.

\subsection{Petrogenetic Constraints}

High-potassic (lamproitic, kamafugitic and leucititic) melts are believed to originate in extensional tectonic settings from variably enriched lithospheric sources $[1,88,89]$. Physical models, verified by the studies of mantle xenoliths, suggest that melting of SCLM peridotite below thinned continental crust is responsible for the generation of potassic basic/ultrabasic magmas [90]. Although these models were developed primarily on homogeneous peridotite, it is widely accepted that lamproitic melts originate 
in mild-extensional settings from sources with mixed compositions, which are representative of SCLM peridotite, veined by K-rich assemblages $[6,67,88,91]$. Such assemblages often contain phlogopite (or potassic amphibole) and pyroxenes as major phases, while titanian silicates are characteristic of high-Ti lamproites and may not be found in low-Ti counterparts [91]. Kamafugite magma is produced in strong rift-like extension settings and low geothermal gradients. In addition, it requires excess $\mathrm{CO}_{2}$ (presence of carbonate in the source) and $\mathrm{H}_{2} \mathrm{O}[91,92]$.

Although they form in similar geodynamic settings, kamafugites and lamproites originate in substantially different conditions and rarely occur together. However, both types of rocks do occur in some areas of the Mediterranean belt [5,6,67,93-95]. Some studies claim a similar lithospheric source for both lamproites and kamafugites/leucitites, and interpret their contrasting chemistry as a result of different volatile speciation [96]. Nevertheless, many studies imply similar tectonic settings and lithological patterns for SCLM, kamafugites and lamproites, but highlight differences between source mineralogy. According to such models, carbonate-free silica-saturated sources produce lamproitic melts, whereas melting of carbonate-bearing silica-undersaturated assemblages resulted in generation of kamafugite/leucitite [5,67,92,95]. Given that Aldan and Mediterranean lamproites are comparable both in rock and mineral chemistry, and "kamafugitic" olivine-3 has several features characteristic for olivine from Mediterranean kamafugites/leucitites, it is likely that similar mechanisms operated at both localities and we adopt a similar model for this study.

As previously mentioned, we propose that the first melts extracted from the source had distinct kamafugitic affinities, whereas the later melts had lamproitic compositions. There were likely "transitional" members; for example, the Late Jurassic high-Ca lamproitic and lamprophyric rocks [11]. In the context of Mesozoic geodynamics of the Central Aldan area, this implies that the KAM originated during the beginning of the rift-like lithosphere extension, while lamproitic magmatism was produced substantially at later stages of extension. This is further supported by the low Mesozoic geothermal gradient, which fulfills the tectonic requirements for kamafugite generation [90,92]. Adopting commonly accepted models [88,90], we suggest that the KAM was extracted during low-degree extension-triggered melting of SCLM, veined by a phlogopite + clinopyroxene + carbonate \pm orthopyroxene \pm olivine assemblage (Figure 12A,B).

There are two explanations to the origin of the LAM. Firstly, the lamproites may have originated from another part of the lithosphere, which was carbonate-free. Despite its simplicity, this idea raises a question about the nature of such strong SCLM heterogeneity. Although there is a model that suggests that carbonate-rich and carbonate-poor types of SCLM modification produced sources for spatially juxtaposed Mediterranean leucitites and lamproites [67], it is unclear what mechanism was responsible for the heterogeneity. A second possible explanation is that lamproites were generated from the same part of veined SCLM, which experienced modification. This modification might take place during extraction of the KAM and during the gap between "kamafugitic" and "lamproitic" stages. Generation and extraction of the KAM must have affected the source composition considerably by exhausting highly fusible carbonate from the assemblage (Figure 12B). It would also reduce amounts of phlogopite and clinopyroxene with respect to more refractory olivine. Importantly, this would not significantly decrease silica content, which is balanced during clinopyroxene $\left(\sim 55 \mathrm{wt}\right.$. $\left.\% \mathrm{SiO}_{2}\right)$ melting by exhaustion of silica-free carbonate and relatively silica-poor ( $\left.\sim 2 \mathrm{wt} . \% \mathrm{SiO}_{2}\right)$ phlogopite. However, it is unlikely that after the KAM was generated, there would be enough phlogopite to produce ultra-potassic LAM, and the modification of the source would probably demand input of alkalis. Since the estimated temperature of LAM generation (above $1350{ }^{\circ} \mathrm{C}$ ) is significantly higher than required for KAM generation, we suggest that there was a deep thermal flux, which may also have supplied $\mathrm{K}$ and $\mathrm{Si}$ to the source [19] (Figure 12C). The suggestion of substantial input of mobile alkaline and alkali-earth elements in the source during the Mesozoic is also supported by a high dispersion of $\mathrm{Sr}$ and $\mathrm{Nd}$ isotope compositions of the Aldan lamproites, with Sr being generally more primitive than $\mathrm{Nd}[12,30,36,97,98]$. This modified SCLM, veined by a clinopyroxene + phlogopite + orthopyroxene \pm olivine assemblage, 
along with thermal and tectonic (continuing extension) conditions were sufficient for the generation of ultrapotassic silica-saturated melts of lamproitic affinity [6,67,88,91,99] (Figure 12D).

After their generation, both melts ascended and accumulated within underplated chambers (Figure 14A). As a significant volume of the LAM approached the mantle-crust boundary, the KAM, which was generated slightly before the LAM, was likely already partially crystallized (Figure 14A). Partially crystallized assemblages of the KAM (olivine-3 and less refractory minerals) were then assimilated with the LAM, which was much more volumetrically significant. During assimilation, less refractory minerals of the KAM (phlogopite, monticellite etc.) were melted, whereas some olivine grains survived and were preserved in lamproites (e.g., olivine-3, Figure 14B). Subsequent slow-cooling within the underplated magma chambers produced a second generation of olivine (olivine-2), which may also have partially formed during LAM upwelling (Figure 14A-C). Ongoing tectonic events resulted in fracturing of the crust and further upwelling of magma, culminating in crystallization within shallow-level chambers and as small intrusions (Figure 14C,D). During this process, dynamic cooling and variable physicochemical conditions produced the compositional zonation observed in olivine-1.

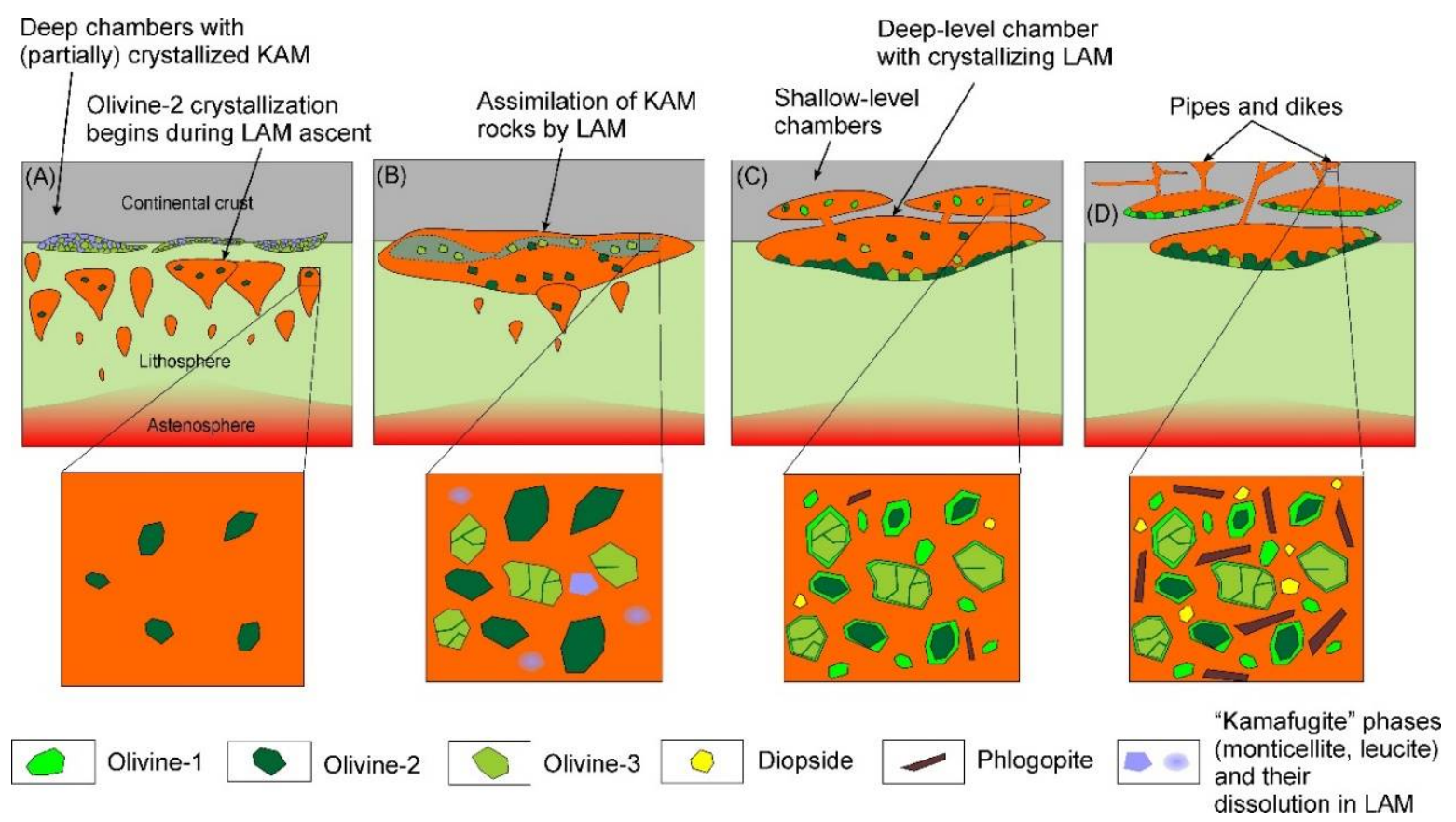

Figure 14. Schematic outlining processes of magma assimilation and the olivine crystallization sequence (types 1-3). (A) Uprise of a newly formed lamproite melt; (B) Accumulation of the lamproite melt in under-plated chambers and partial assimilation of cumulates, crystallized from a kamafugite-like melt; (C) crystallization of the resulting magma in deep- and shallow-level chambers; (D) emplacement of subvolcanic intrusions and ultimate solidification of the rocks.

The question remains as to the origin of the veined SCLM. Data presented here imply a carbonate-potassium-rich modification of initially depleted SCLM. Tectonic processes such as subduction and collision have been postulated as the mechanism for such a modification in the Mediterranean belt, proposing that most components (alkali, silica, carbonate) originated from either a subducted slab or sediments, which were accreted into the lithosphere $[4,5,7,18,67,95,96,100]$. However, similar processes are not applicable to the Central Aldan area, at least during the Phanerozoic, as it was distant $(>1000 \mathrm{~km})$ from any active margins and orogenic belts. In addition, isotopic data $[30,97,98]$ indicates that the SCLM in the Central Aldan area is ancient and strongly enriched (initial $\varepsilon(\mathrm{Nd}) \sim$ -15--22). Moreover, trace element compositions of olivine, although being similar to that of the Mediterranean lamproites, has significantly lower Zn and Li (Figure 10A), which are often used 
as tracers of crust recycling [18]. Therefore, although the nature of the SCLM beneath the Central Aldan remains enigmatic, the subduction-driven model of its modification remains doubtful. Rather, the overlapping of the Proterozoic-Mesozoic "carbonatite-apatite" zone with the Central Aldan province $[27,28,30]$ provides additional evidence of a Precambrian age for the veined SCLM below the studied area.

\section{Conclusions}

Four generations of olivine were identified in the Ryabinoviy pipe low-Ti lamproites:

1. Olivine phenocrysts with step-like regular zoning and a broad compositional range.

2. High-Mg, high-Ni olivine macrocrysts, considered to be the earliest olivine, crystallized from lamproite magma and stored in cumulate layers.

3. Olivine crystallized from kamafugite-like alkaline magma, and subsequently trapped within the lamproitic magma as xenocrysts or intergrowths.

4. Mantle-derived xenocrysts.

We consider olivine-3 to represent a fingerprint of small-scale kamafugite-like magmatism, which, along with other forms of alkaline magmatism, took place during the Mesozoic activation of the Aldan Shield. Kamafugite-like melts were likely generated during low-temperature extension-triggered melting of the SCLM, modified by veins of carbonate- and potassium-bearing assemblages. Subsequent generation of lamproitic melts occurred at higher (up to $1350{ }^{\circ} \mathrm{C}$ ) temperatures either from initially different parts of the SCLM, veined by carbonate-free assemblages or from the same part, and later modified by kamafugite extraction and the input of external K and Si from an unknown source. Oxygen fugacity in the lamproitic melt was three -four units above NNO buffer; higher than the estimates for other lamproites worldwide. The Kamafugite-like melt is deemed to be even more oxidized than the lamproite melt, based on the extremely low V/Sc ratio in the "kamafugitic" olivine. However, these calculations should be considered as rough proxies only, as several assumptions and re-calculations were applied to the oxybarometer [82-84,86,87].

As spatially-associated kamafugitic/leucititic and lamproitic types of magmatism are characteristic of low-Ti potassic magmatism from the Mediterranean belt, our study provides further evidence of the similarities between the Aldan and the Mediterranean regions. However, the Central Aldan potassic province lies within typically-cratonic settings, and there are no robust signatures of subducted matter involved in its origin. Therefore, our study also shows that recycled subduction components are not an essential factor in the petrogenesis of low-Ti lamproites, kamafugites and leucitites.

Supplementary Materials: The following are available online at http://www.mdpi.com/2075-163X/10/4/337/s1, Table S1: bulk chemical compositions of the Ryabinoviy pipe lamproites; Table S2: compositions of olivine from the Ryabinoviy pipe lamproites; Table S3: compositions of the experimentally-obtained glasses of the olivine-hosted inclusions; Table S4: compositions of olivine-hosted inclusions of $\mathrm{Cr}$-spinel from the Ryabinoviy pipe lamproites; Table S5: Temperature and oxygen fugacity parameters calculated using olivine-chromite pair compositions.

Author Contributions: I.F.C. and A.E.I. studied the rocks on field trips and prepared the original draft. A.V.S. provided supervision of the study and helped with the data interpretation. A.V.S., V.G.B. and S.P.K. elaborated the study methodology, experimental technique and performed microprobe data acquisition. A.K.-C. and A.V.K. substantially reviewed and edited the text. A large volume of LA ICP-MS and SEM EDS examination was performed by M.V.C., B.M.L. and V.S.C. All authors have read and agreed to the published version of the manuscript.

Funding: The study was conducted under the State Assignment to V.S. Sobolev Institute of Geology and Mineralogy SB RAS and was supported by the Russian Science Foundation grant 19-17-00019. Analytical studies in France were supported by the Labex OSUG@2020 grant (Investissements d'avenir-ANR10 LABX56). Analytical studies in IGG UB RAS (Yekaterinburg) and SFU (Krasnoyarsk) were carried out under partial support of the Russian Science Foundation grant 16-17-10283 and RFBR grant 19-05-00300, respectively.

Acknowledgments: The authors thank the two anonymous Reviewers for a substantial contribution to the article improvement. We thank A.V.Nikiforov, who provided samples, collected in collaborative fieldwork with A.E.I., V.A. Danilovskaya, V.N. Korolyuk, D.V. Kuzmin and S.G. Simakin for technical assistance in microprobe investigations, E.V. Asafov for assistance in experimental work and melt inclusions' preparation, V.N. Knyazev 
for SEM assistance and A.V. Lavrenchuk for help with statistical processing of data. We kindly acknowledge for considerable support RSF project leader A.G. Doroshkevich. We are also grateful to I. Yu. Safonova for informal discussion and to A.V. Iskrina for substantial encouraging C.I.F. during the preparation of this manuscript.

Conflicts of Interest: The authors declare no conflicts of interest.

\section{Appendix A}

Although the examined olivine grains contain plenty of secondary inclusions, located along healed fractures, we studied only those that can be considered primary. This is based on them being larger than secondary inclusions and occurring sporadically without affiliation to any linear structures within the grain. Since olivine can originate in different settings and experience post-crystallization transformation, recrystallization and dissolution-reaction-mixing processes [101], there is no guarantee that the inclusions are representative of trapped melt. Typically, melt inclusions, entrapped during mineral growth, are round or elliptical and require the presence of glass with optional daughter phases and a gas bubble [102]. In this case, there is no bona fide glass observed within non-heated inclusions, which might indicate a non-melt origin of these inclusions; rather, they represent heterogeneous entrapment of solid mineral phases.

If the major phases of phlogopite, clinopyroxene and monticellite, are entrapped heterogeneously, the composition of the inclusions is controlled by the volume of each phase. On binary major element plots, this should be reflected in trends, lying between "end members" of the major minerals, while trace element concentrations must be averages of those typical for phlogopite, clinopyroxene (and monticellite). In this case, major element compositions provided no clear evidence of whether the examined inclusions are mixtures of heterogeneously trapped phlogopite and clinopyroxene (monticellite). Therefore, we used trace elements as a means of discrimination. Obtained by SIMS, several compositions of phlogopite and diopside from the inclusions show broad variations of the trace element contents, although the glasses of the heated inclusions contain significantly higher concentrations of most incompatible lithophiles (Figure A1). Based on the small size of such inclusions $(<10 \mu \mathrm{m})$, neighboring phases can strongly distort the compositions obtained by SIMS. Therefore, we additionally analyzed several phenocrysts of those minerals in olivine-diopside-phlogopite lamproite using laser ablation ICP-MS (sample I55-6-12). The results, plotted on the PM-normalized spider-diagram (Figure A1), show sufficient coincidence between SIMS and LA-ICP-MS data and indicate that concentrations of incompatible lithophile elements within the inclusions are not supported by clinopyroxene (almost barren in LILE and HFSE) and phlogopite phenocrysts. Moreover, trace element spectra of the heated inclusions' glasses vary in a significantly narrower range than those of phlogopite and clinopyroxene and are similar to the spectra of whole-rock compositions. Hence, there is enough data to suggest that the studied inclusions were entrapped as melt and then fully crystallized.

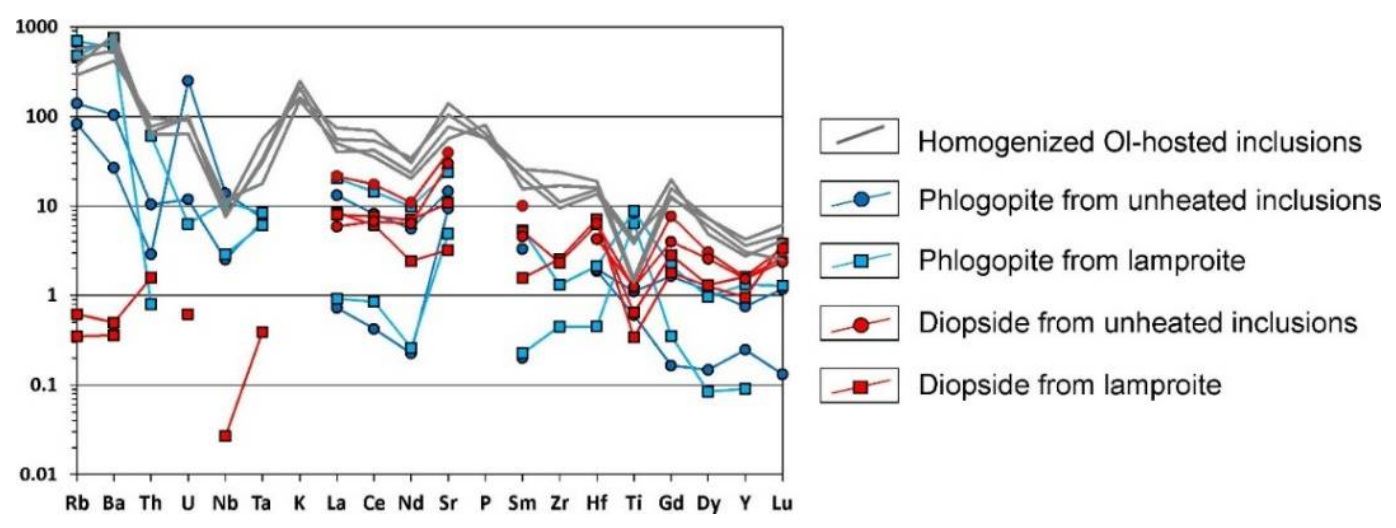

Figure A1. PM-normalized spider-diagram for compositions of clinopyroxene and phlogopite from olivine-hosted inclusions (SIMS data), the silicate rock matrix (LA-ICP-MS data) and the glasses of homogenized olivine-hosted inclusions (SIMS data). 


\section{References}

1. Mitchell, R.H.; Bergman, S.C. Petrology of Lamproites; Springer: New York, NY, USA, 1991; p. 447.

2. Woolley, A.R.; Bergman, S.C.; Edgar, A.D.; Le Bas, M.J.; Mitchell, R.H.; Rock, N.M.S.; Smith, B.H.S. Classification of lamprophyres, lamproites, kimberlites, and the kalsilitic, melilitic, and leucitic rocks. Can. Miner. 1996, 34, 175-186.

3. Foley, S.F.; Venturelli, G.; Green, D.H.; Toscani, L. The Ultrapotassic Rocks-Characteristics, Classification, and Constraints for Petrogenetic Models. Earth Sci. Rev. 1987, 24, 81-134. [CrossRef]

4. Prelevic, D.; Foley, S.F.; Romer, R.; Conticelli, S. Mediterranean tertiary lamproites derived from multiple source components in postcollisional geodynamics. Geochim. Cosmochim. Acta 2008, 72, 2125-2156. [CrossRef]

5. Conticelli, S.; Laurenzi, M.A.; Giordano, G.; Avanzinelli, R.; Melluso, L.; Tommasini, S.; Boari, E. Leucite-beaing (kamafugitic/leucititic) and -free (lamproitic) ultrapotassic rocks and associated shoshonites from Italy: Constraints on petrogenesis and geodynamics. J. Virtual Explor. 2010, 36, 20. [CrossRef]

6. Prelevic, D.; Foley, S.F.; Romer, R.L.; Cvetkovic, V.; Downes, H. Tertiary ultrapotassic volcanism in Serbia: Constraints on petrogenesis and mantle source characteristics. J. Pet. 2005, 46, 1443-1487. [CrossRef]

7. Prelevic, D.; Foley, S.F. Accretion of arc-oceanic lithospheric mantle in the Mediterranean: Evidence from extremely high-Mg olivines and Cr-rich spinel inclusions in lamproites. Earth Planet Sci. Lett. 2007, 256, 120-135. [CrossRef]

8. Khomich, V.G.; Boriskina, N.G.; Santosh, M. Geodynamics of late Mesozoic PGE, Au, and U mineralization in the Aldan shield, North Asian Craton. Ore Geol. Rev. 2015, 68, 30-42. [CrossRef]

9. Bilibin, Y.A. Petrography of Aldan. Post-Jurassic Intrusions of the Aldan region. Selected Works; AN SSSR: Moscow, Russia, 1958; Volume 1. (In Russian)

10. Bilibina, T.V.; Dashkova, A.D.; Donakov, V.I.; Titov, V.K.; Shchukin, S.I. Petrology of the alkaline volcanogenic-intrusive complex of the Aldan Shield (Mesozoic); Nedra: Leningrad, Russia, 1967. (In Russian)

11. Bogatikov, O.A. Lamproites; Nauka: Moscow, Russia, 1991. (In Russian)

12. Davies, G.R.; Stolz, A.J.; Mahotkin, I.L.; Nowell, G.M.; Pearson, D.G. Trace element and Sr-Pb-Nd-Hf isotope evidence for ancient, fluid-dominated enrichment of the source of Aldan shield lamproites. J. Pet. 2006, 47, 1119-1146. [CrossRef]

13. Panina, L.I.; Vladykin, N.V. Lamproite rocks of Murun massif and their origin. Geol. Geofiz. 1994, 35, $100-113$. (In Russian)

14. Rokosova, E.Y.; Panina, L.I. Shonkinites and minettes of the Ryabinovyi massif (Central Aldan): Composition and crystallization conditions. Russ. Geol. Geophys. 2013, 54, 613-626. [CrossRef]

15. Sharygin, V.V. Potassic picrites of Ryabinoviy massif (Central Aldan). Geol. Geofiz. 1993, 4, 60-70. (In Russian)

16. Vladykin, N.V. Geochemistry and genesis of lamproites of the Aldan shield. Geol. Geofiz. 1997, 38, $123-135$. (In Russian)

17. Batanova, V.G.; Sobolev, A.V.; Magnin, V. Trace element analysis by EPMA in geosciences: Detection limit, precision and accuracy. Iop Conf. Ser. Mater. Sci. Eng. 2018, 304, 149-157. [CrossRef]

18. Foley, S.F.; Prelevic, D.; Rehfeldt, T.; Jacob, D.E. Minor and trace elements in olivines as probes into early igneous and mantle melting processes. Earth Planet. Sc. Lett. 2013, 363, 181-191. [CrossRef]

19. Sobolev, A.; Hofmann, A.; Kuzmin, D.; Yaxley, G.; Arndt, N.; Chung, S.-L.; Danyushevsky, L.; Elliott, T.; Frey, F.; Garcia, M.; et al. The Amount of Recycled Crust in Sources of Mantle-Derived Melts. Science 2007, 316, 412-417. [CrossRef]

20. Veter, M.; Foley, S.F.; Mertz-Kraus, R.; Groschopf, N. Trace elements in olivine of ultramafic lamprophyres controlled by phlogopite-rich mineral assemblages in the mantle source. Lithos 2017, 292, 81-95. [CrossRef]

21. Gurenko, A.A.; Chaussidon, M. Enriched and depleted primitive melts included in olivine from Icelandic tholeites: origin by continuous melting of a single mantle column. Geochim. et Cosmochim. Acta 1995, 59, 2905-2917. [CrossRef]

22. Kamenetsky, V.; Métrich, N.; Cioni, R. Potassic primary melts of Vulsini (Roman Province): Evidence from mineralogy and melt inclusions. Contrib. Miner. Petr. 1995, 120, 186-196. [CrossRef]

23. Sobolev, A.V. Melt inclusions in minerals as a source of principle petrological information. Petrology 1996, 4, 228-239. 
24. Sobolev, A.V.; Asafov, E.V.; Gurenko, A.A.; Arndt, N.T.; Batanova, V.G.; Portnyagin, M.V.; Garbe-Schonberg, D.; Krasheninnikov, S.P. Komatiites reveal a hydrous Archaean deep-mantle reservoir. Nature 2016, 531, 628-632. [CrossRef]

25. Jaques, A.L.; Foley, S.F. Insights into the petrogenesis of the West Kimberley lamproites from trace elements in olivine. Min. Pet. 2018, 112, 519-537. [CrossRef]

26. Panina, L.I. Low-titanium Aldan lamproites (Siberia): Melt inclusions in minerals. Geol. Geofiz. 1997, 38, 112-122.

27. Entin, A.; Tyan, O. Before-Carbonatite Step of Formation of Apatite Deposits of Seligdar Type (Aldan); Siberian Branch, Acad Sci USSR: Yakutsk, Russia, 1984; Volume 28.

28. Parfenov, L.M.; Kuz'min, M.I. Metallogenic units of North-Asian craton. In Tectonics, geodynamics and metallogeny of the Sakha Republic (Yakutia); Parfenov, L.M.; Kuz'min, M.I. MAIK Nauka Interperiodica: Moscow, Russia, 2001; pp. 301-333.

29. Khomich, V.; Boriskina, N. Structural position of large gold ore districts in the Central Aldan (Yakutia) and Argun (Transbaikalia) superterranes. Russ. Geol. Geophys. 2010, 51, 661-671. [CrossRef]

30. Doroshkevich, A.G.; Prokopyev, I.R.; Izokh, A.E.; Klemd, R.; Ponomarchuk, A.V.; Nikolaeva, I.V.; Vladykin, N.V. Isotopic and trace element geochemistry of the Seligdar magnesiocarbonatites (South Yakutia, Russia): Insights regarding the mantle evolution beneath the Aldan-Stanovoy shield. J. Asian Earth Sci. 2018, 154, 354-368. [CrossRef]

31. Maximov, E.P.; Uyutov, V.I.; Nikitin, V.M. The Central Aldan gold-uranium ore magmatogenic system, Aldan-Stanovoy shield, Russia. Russ. J. Pac. Geol. 2010, 4, 95-115. [CrossRef]

32. Jahn, B.M.; Gruau, G.; Capdevila, R.; Cornichet, J.; Nemchin, A.; Pidgeon, R.; Rudnik, V.A. Archean crustal evolution of the Aldan Shield, Siberia: Geochemical and isotopic constraints. Precambrian Res. 1998, 91, 333-363. [CrossRef]

33. Smelov, A.P.; Timofeev, V.F. The tectonics and metallogeny of the Precambrian of the Aldan-Stanovoy Shield. Proceedings of Mineral Deposit Research: Meeting the Global Challenge, Beijing, China, 18-21 August 2005; Springer: Berlin/Heidelberg, Germany, 2005; pp. 53-56.

34. Gladkochub, D.; Pisarevsky, S.; Donskaya, T.; Natapov, L.; Mazukabzov, A.; Stanevich, A.; Sklyarov, E. Siberian Craton and its evolution in terms of Rodinia hypothesis. Epis. Newsmag. Int. Union Geol. Sci. 2006, 29, 169-174. [CrossRef]

35. Kononova, V.A.; Pervov, V.A.; Bogatikov, O.A.; Mues-Schumacher, U.; Keller, I. Mesozoic potassic magmatism of the Central Aldan: Geodynamics and genesis. Geotectonics 1995, 29, 224-234.

36. Mues-Schumacher, U.; Keller, J.S.; Kononova, V.A.; Suddaby, P. Petrology and age determinations of the ultramafic (lamproitic) rocks form the Yakokut complex, Aldan Shield, Eastern Siberia. Mineral. Mag. 1995, 59, 409-428. [CrossRef]

37. Chayka, I.F.; Izokh, A.E.; Sobolev, A.V.; Batanova, V.G.; Lobastov, B.M. Evolution of low-Ti lamproite rock series from Ryabinoviy massif (Aldan shield, Russia) and connected carbonatite-hydrothermal mineralization. Proceedings of Petrology of Magmatic and Metamorphic Complexes, Tomsk, Russia; 2017; pp. 441-447.

38. Batanova, V.G.; Sobolev, A.V.; Kuzmin, D.V. Trace element analysis of olivine: High precision analytical method for JEOL JXA-8230 electron probe microanalyser. Chem. Geol. 2015, 419, 149-157. [CrossRef]

39. Batanova, V.G.; Thompson, J.M.; Danyushevsky, L.V.; Portnyagin, M.V.; Garbe-Schönberg, D.; Hauri, E.; Kimura, J.-I.; Chang, Q.; Senda, R.; Goemann, K.; et al. New Olivine reference material for in-situ microanalysis. Geostand. Geoanalytical Res. 2019, 43, 453-473. [CrossRef]

40. Krasheninnikov, S.P.; Sobolev, A.V.; Batanova, V.G.; Kargaltsev, A.A.; Borisov, A.A. Experimental testing of olivine-melt equilibrium models at high temperatures. Dokl. Earth Sci. 2017, 475, 919-922. [CrossRef]

41. Morgan, G.B.V.; London, D. Optimizing the electron microprobe analysis of hydrous alkali aluminosilicate glasses. Am. Miner. 1996, 81, 1176-1185. [CrossRef]

42. Jochum, K.P.; Dingwell, D.B.; Roscholl, A.; Stoll, B.; Hoffmann, A.W.; Becker, S.; Besmehn, A.; Bessette, D.; Dietze, H.-J.; Dulski, P.; et al. The Preparation and Preliminary Characterisation of Eight Geological MPI-DING Reference Glasses for In-Situ Microanalysis. Geostand. Newslett. 2000, 24, 87-133. [CrossRef]

43. Jochum, K.P.; Stoll, B.; Herwig, K.; Willbold, M.; Hofmann, A.W.; Amini, M.; Aarburg, S.; Abouchami, W.; Hellebrand, E.; Mocek, B.; et al. MPI-DING reference glasses for in situ microanalysis: New reference values for element concentrations and isotope ratios. Geochem. Geophys. Geosyst. 2006, 7, Q02008. [CrossRef] 
44. Rocholl, A.B.E.; Simon, K.; Jochum, K.P.; Molzahn, M.; Pernicka, E.; Seufert, M.; Spettel, B.; Stummeier, J. Chemical characterization of NIST Silicate Glass Certified Reference Material SRM 610 by ICP-MS, TIMS, LIMS, SSMS, INAA, AAS and PIXE. Geostandards 1997, 21, 101-114. [CrossRef]

45. Shishkina, T.A.; Botcharnikov, R.E.; Holtz, F.; Almeev, R.R.; Portnyagin, M.V. Solubility of $\mathrm{H}_{2} \mathrm{O}-$ and $\mathrm{CO}_{2}$-bearing fluids in tholeiitic basalts at pressures up to $500 \mathrm{MPa}$. Chem. Geol. 2010, 277, 115-125. [CrossRef]

46. Gurenko, A.A.; Belousov, A.B.; Trumbull, R.B.; Sobolev, A.V. Explosive basaltic volcanism of the Chikurachki Volcano (Kurile arc, Russia): Insights on pre-eruptive magmatic conditions and volatile budget revealed from phenocryst-hosted melt inclusions and groundmass glasses. J. Volcanol. Geotherm. Res. 2005, 147, 203-232. [CrossRef]

47. Bucholz, C.E.; Gaetani, G.A.; Behn, M.D.; Shimizu, N. Post-entrapment modification of volatiles and oxygen fugacity in olivine-hosted melt inclusions. Earth Planet Sci. Lett. 2013, 374, 145-155. [CrossRef]

48. Danyushevsky, L.V.; McNeill, A.W.; Sobolev, A.V. Experimental and petrological studies of melt inclusions in phenocrysts from mantle-derived magmas: An overview of techniques, advantages and complications. Chem. Geol. 2002, 183, 5-24. [CrossRef]

49. Gaetani, G.A.; O'Leary, J.A.; Shimizu, N.; Bucholz, C.E.; Newville, M. Rapid reequilibration of $\mathrm{H}_{2} \mathrm{O}$ and oxygen fugacity in olivine-hosted melt inclusions. Geology 2012, 2012 40, 915-918. [CrossRef]

50. Portnyagin, M.; Almeev, R.; Matveev, S.; Holtz, F. Experimental evidence for rapid water exchange between melt inclusions in olivine and host magma. Earth Planet. Sci. Lett. 2008, 272, 541-552. [CrossRef]

51. Sun, S.; McDonough, W.F. Chemical and isotopic systematics of oceanic basalts: Implications for mantle composition and processes. Geol. Soc. Lond. Spec. Publ. 1989, 42, 313-345. [CrossRef]

52. Boynton, W.V. Cosmochemistry of the rare earth elements: Meteorite studies. In Developments in Geochemistry; Elsevier: Amsterdam, The Netherlands, 1984; Volume 2, pp. 63-114.

53. Le Maitre, R.W. (Ed.) Igneous Rocks. A Classification and Glossary of Terms. Recommendations of the International Union of Geological Sciences Subcomission on the Systematics of Igneous Rocks, 2nd ed.; Cambridge University Press: Cambridge, UK, 2002; p. 236.

54. Hoa, T.T.; Thanh, H.H.; Phuong, N.T.; Anh, T.T.; Hang, H.V. Mineralization, characteristics and forming conditions of lamproite of Vietnam. J. Geol. Ser. B 1997, 9-10, 63-68.

55. Mitchell, R.H.; Platt, R.G.; Downey, M. Petrology of Lamproites from Smoky Butte, Montana. J. Pet. 1987, 28, 645-677. [CrossRef]

56. Plechov, P.Y.; Shcherbakov, V.D.; Nekrylov, N.A. Extremely magnesian olivine in igneous rocks. Russ. Geol. Geophys. 2018, 59, 1702-1717. [CrossRef]

57. Sobolev, A.V.; Hofmann, A.W.; Sobolev, S.V.; Nikogosian, I.K. An olivine-free mantle source of Hawaiian shield basalts. Nature 2005, 434, 590-597. [CrossRef]

58. Arndt, N.; Guitreau, M.; Boullier, A.-M.; Le Roex, A.; Tommasi, A.; Cordier, P.; Sobolev, A. Olivine, and the origin of kimberlite. J. Pet. 2010, 51, 573-602. [CrossRef]

59. Kamenetsky, V.S.; Kamenetsky, M.B.; Sobolev, A.V.; Golovin, A.V.; Demouchy, S.; Faure, K.; Sharygin, V.V.; Kuzmin, D.V. Olivine in the Udachnaya-East Kimberlite (Yakutia, Russia): Types, Compositions and Origins. J. Pet. 2007, 49, 823-839. [CrossRef]

60. Deer, W.A.; Howie, R.A.; Zussman, J. Rock-Forming Minerals: Single-Chain Silicates. Geological Society of London: London, UK, 1997; Volume 2, p. 662.

61. Zharikov, V.A. Skarns (Part I). Int. Geol. Rev. 1970, 12, 541-559. [CrossRef]

62. Shatova, N.V. Ore potential of hydrothermal-metasomatic formations of the Ryabinovoye ore field (Southern Yakutiya). Ph.D. Thesis, VSEGEI, Saint-Petersburg, Russia, 2016. (In Russian).

63. Ersoy, Ö.; Nikogosian, I.K.; van Bergen, M.J.; Mason, P.R. Phosphorous incorporation in olivine crystallized from potassium-rich magmas. Geochim. Cosmochim. Acta 2019, 253, 63-83. [CrossRef]

64. Krmíček, L.; Romer, R.L.; Ulrych, J.; Glodny, J.; Prelević, D. Petrogenesis of orogenic lamproites of the Bohemian Massif: $\mathrm{Sr}-\mathrm{Nd}-\mathrm{Pb}-\mathrm{Li}$ isotope constraints for Variscan enrichment of ultra-depleted mantle domains. Gondwana Res. 2016, 35, 198-216. [CrossRef]

65. Sobolev, A.V.; Sobolev, S.V.; Kuzmin, D.V.; Malitch, K.N.; Petrunin, A.G. Siberian meimechites: Origin and relation to flood basalts and kimberlites. Russ. Geol. Geophys. 2009, 50, 999-1033. [CrossRef]

66. Giuliani, A. Insights into kimberlite petrogenesis and mantle metasomatism from a review of the compositional zoning of olivine in kimberlites worldwide. Lithos 2018, 312-313, 322-342. [CrossRef] 
67. Ammannati, E.; Jacob, D.E.; Avanzinelli, R.; Foley, S.F.; Conticelli, S. Low Ni olivine in silica-undersaturated ultrapotassic igneous rocks as evidence for carbonate metasomatism in the mantle. Earth Planet. Sci. Lett. 2016, 444, 64-74. [CrossRef]

68. Di Rocco, T.; Freda, C.; Gaeta, M.; Mollo, S.; Dallai, L. Magma chambers emplaced in carbonate substrate: Petrogenesis of skarn and cumulate rocks and implications for $\mathrm{CO}_{2}$ degassing in volcanic areas. J. Pet. 2012, 53, 2307-2332. [CrossRef]

69. Cortes, J.A.; Wilson, M.; Condliffe, E.; Francalanci, L. The occurrence of forsterite and highly oxidizing conditions in basaltic lavas from Stromboli volcano, Italy. J. Pet. 2006, 47, 1345-1373. [CrossRef]

70. Niida, K. Textures and olivine fabrics of the Horoman ultramafic rocks, Japan. J. Jpn. Assoc. Mineral. Petrol. Econ. Geol. 1975, 70, 265-285. [CrossRef]

71. Bussweiler, Y.; Brey, G.; Pearson, D.; Stachel, T.; Stern, R.; Hardman, M.; Kjarsgaard, B.; Jackson, S. The aluminum-in-olivine thermometer for mantle peridotites-Experimental versus empirical calibration and potential applications. Lithos 2017, 272, 301-314. [CrossRef]

72. Sobolev, N.V.; Logvinova, A.M.; Zedgenizov, D.A.; Pokhilenko, N.P.; Kuzmin, D.V.; Sobolev, A.V. Olivine inclusions in Siberian diamonds: High-precision approach to minor elements. Eur. J. Miner. 2008, 20, 305-315. [CrossRef]

73. Sobolev, N.V.; Logvinova, A.M.; Zedgenizov, D.A.; Pokhilenko, N.P.; Malygina, E.V.; Kuzmin, D.V.; Sobolev, A.V. Petrogenetic significance of minor elements in olivines from diamonds and peridotite xenoliths from kimberlites of Yakutia. Lithos 2009, 112, 701-713. [CrossRef]

74. Gaul, O.F.; Griffin, W.L.; O’Reilly, S.Y.; Pearson, N.J. Mapping olivine composition in the lithospheric mantle. Earth Planet. Sci. Lett. 2000, 182, 223-235. [CrossRef]

75. Bernstein, S.; Kelemen, P.B.; Hanghøj, K. Consistent olivine Mg\# in cratonic mantle reflects Archean mantle melting to the exhaustion of orthopyroxene. Geology 2007, 35, 459-462.

76. De Hoog Jan, C.M.; Gall, L.; Cornell, D.H. Trace-element geochemistry of mantle olivine and application to mantle petrogenesis and geothermobarometry. Chem. Geol. 2010, 270, 196-215. [CrossRef]

77. O'Reilly, S.Y.; Chen, D.; Griffin, W.L.; Ryan, C.G. Minor elements in olivine from spinel lherzolite xenoliths: Implications for thermobarometry. Mineral. Mag. 1997, 61, 257. [CrossRef]

78. Sharygin, I.; Nikolenko, E.; Lobov, K. Carbonate inclusions in Cr-pyropes derived from the mantle beneath Central Aldan superterrane of Siberian craton. In Proceedings of the 11th International Kimberlite Conference, Gaborone, Botswana, 18-22 September 2017. Extended Abstract No. 11IKC-4609.

79. Pollack, H.N.; Chapman, D.S. On the regional variation of heat flow, geotherms, and lithospheric thickness. Tectonophysics 1977, 38, 279-296. [CrossRef]

80. Mitchell, R.H. Melting Experiments on a Sanidine Phlogopite Lamproite at 4-7 Gpa and Their Bearing on the Sources of Lamproitic Magmas. J. Pet. 1995, 36, 1455-1474. [CrossRef]

81. Coogan, L.A.; Saunders, A.D.; Wilson, R.N. Aluminum-in-olivine thermometry of primitive basalts: Evidence of an anomalously hot mantle source for large igneous provinces. Chem. Geol. 2014, 368, 1-10. [CrossRef]

82. Ballhaus, C.; Berry, R.; Green, D. High pressure experimental calibration of the olivine-orthopyroxene-spinel oxygen geobarometer: Implications for the oxidation state of the upper mantle. Contrib. Mineral. Petrol. 1991, 107, 27-40. [CrossRef]

83. Foley, S.F. The oxidation state of lamproitic magmas. Tschermaks Mineral. Und Petrogr. Mitt. 1985, 34, $217-238$. [CrossRef]

84. Tappe, S.; Foley, S.; Jenner, G.; Heaman, L.M.; Kjarsgaard, B.; Romer, R.; Stracke, A.; Joyce, N.; Hoefs, J. Genesis of Ultramafic Lamprophyres and Carbonatites at Aillik Bay, Labrador: A Consequence of Incipient Lithospheric Thinning beneath the North Atlantic Craton. J. Pet. 2006, 47, 1261-1315. [CrossRef]

85. Canil, D. Vanadium partitioning and the oxidation state of Archaean komatiite magmas. Nature 1997, 389, 842. [CrossRef]

86. Fedortchouk, Y.; Canil, D. Intensive variables in kimberlite magmas, Lac de Gras, Canada and implications for diamond survival. J. Pet. 2004, 45, 1725-1745. [CrossRef]

87. Stormer, J. Calcium zoning in olivine and its relationship to silica activity and pressure. Geochim. Cosmochim. Acta 1973, 27, 1815-1821. [CrossRef]

88. Foley, S. Petrological Characterization of the Source Components of Potassic Magmas-Geochemical and Experimental Constraints. Lithos 1992, 28, 187-204. [CrossRef] 
89. Gupta, A.K. Origin of Potassium-Rich Silica-Deficient Igneous Rocks; Springer: Berlin/Heidelberg, Germany, 2015; p. 546. [CrossRef]

90. McKenzie, D. Some remarks on the movement of small melt fractions in the mantle. Earth Planet. Sci. Lett. 1989, 95, 53-72. [CrossRef]

91. Foley, S.F. An experimental study of olivine lamproite: First results from the diamond stability field. Geochim. Cosmochim. Acta 1993, 57, 483-489. [CrossRef]

92. Bailey, D.K.; Collier, J.D. Carbonatite-melilitite association in the Italian collision zone and the Ugandan rifted craton: Significant common factors. Miner. Mag. 2000, 64, 675-682. [CrossRef]

93. Cundari, A.; Ferguson, A.K. Petrogenetic relationships between melilitite and lamproite in the Roman Comagmatic Region: The lavas of S. Venanzo and Cupaello. Contrib. Miner. Petr. 1991, 107, 343-357. [CrossRef]

94. Conticelli, S.; Peccerillo, A. Petrology and geochemistry of potassic and ultrapotassic volcanism in central Italy: Petrogenesis and inferences on the evolution of the mantle sources. Lithos 1992, 28, 221-240. [CrossRef]

95. Conticelli, S.; Avanzinelli, R.; Ammannati, E.; Casalini, M. The role of carbon from recycled sediments in the origin of ultrapotassic igneous rocks in the Central Mediterranean. Lithos 2015, 232, 174-196. [CrossRef]

96. Avanzinelli, R.; Lustrino, M.; Mattei, M.; Melluso, L.; Conticelli, S. Potassic and ultrapotassic magmatism in the circum-Tyrrhenian region: Significance of carbonated pelitic vs. pelitic sediment recycling at destructive plate margins. Lithos 2009, 113, 213-227. [CrossRef]

97. Chayka, I.F.; Vasyukova, E.A. Mineralogy, geochemistry and isotopy of lamproitic rocks of the Tobuk complex and their connection with Au-bearing Ryabinoviy massif (Central Aldan). Metallog. Anc. Present Ocean. 2017, 1, 232-337. (In Russian)

98. Vladykin, N.V. Geochemistry of Sr and Nd isotopes of alkaline and carbonatite complexes in Siberia and Mongolia; some geodynamic implications. In Problems of Sources of Deep Magmatism and Plumes; Glazkovskaya Printing House: Irkutsk, Russia, 2005; pp. 13-29. (In Russian)

99. Edgar, A.; Pizzolato, L.; Sheen, J. Fluorine in igneous rocks and minerals with emphasis on ultrapotassic mafic and ultramafic magmas and their mantle source regions. Miner. Mag. 1996, 60, 243-257. [CrossRef]

100. Peccerillo, A. Relationships between ultrapotassic and carbonate-rich volcanic rocks in central Italy: Petrogenetic and geodynamic implications. Lithos 1998, 43, 267-279. [CrossRef]

101. Danyushevsky, L.V.; Leslie, R.A.; Crawford, A.J.; Durance, P. Melt inclusions in primitive olivine phenocrysts: The role of localized reaction processes in the origin of anomalous compositions. J. Petrol. 2004, 45, 2531-2553. [CrossRef]

102. Frezzotti, M.-L. Silicate-melt inclusions in magmatic rocks: Applications to petrology. Lithos 2001, 55, $273-299$. [CrossRef]

(C) 2020 by the authors. Licensee MDPI, Basel, Switzerland. This article is an open access article distributed under the terms and conditions of the Creative Commons Attribution (CC BY) license (http://creativecommons.org/licenses/by/4.0/). 